\section{Trakya Eğitim Dergisi}

Cilt 10, Sayı 3

Eylül 2020, 795-814

Geliş Tarihi: 05.11.2019

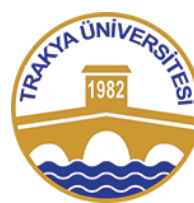

ISSN: 2630-6301

Doi: $10.24315 /$ tred.642786

Araştırma Makalesi/

Research Article
Trakya Journal of Education

Volume 10, Issue 3

September 2020, 795-814

Yayına Kabul Tarihi15.05.2020.

\title{
İlkokullarda Yetiştirme Programında (IYYEP) Karşılaşılan Sorunlar, Paydaşlarına Olan Katkıları ve Çözüm Önerileri
}

\section{Problems Encountered in Remedial Program in Primary Schools (RPPS), Contribution to Stakeholders and Suggestions for Solution}

\section{Sami AYDIN ${ }^{1}$, Levent YAKAR ${ }^{2}$}

Özet: $\mathrm{Bu}$ araştırma, katılımc1 görüşleri doğrultusunda İlkokullarda Yetiştirme Programında (IYYEP) karşıllaşılan sorunları, programın paydaşlarına katkılarını ve program sürecinde yaşanan sorunlara yönelik çözüm önerilerini incelemek amacıyla yapılmıştır. $\mathrm{Bu}$ amaç doğrultusunda olgubilim deseninde gerçekleştirilen araştırmanın çalışma grubunu 20182019 öğretim y1lında Kahramanmaraş ili Dulkadiroğlu ve Onikişubat ilçelerindeki ilkokullarda görev yapan 50 gönüllü öğretmen oluşturmuştur. Araştırmanın verileri yarı yapılandırılmış görüşme formu kullanılarak toplanmıştır. Veriler, içerik analizi yöntemi kullanılarak analiz edilmiştir. IYYEP'te karşılaşılan sorunlar için elde edilen bulgularda katılımcılar IYEP'te program, mevzuat, öğrenci, rehberlik, fiziki alt yapı, öğretmen merkezli sorunlarla karşılaştıklarını belirtmişlerdir. Programın paydaşlara katkılarına yönelik bulgularda ise öğretmenler İYEP'i uygulayarak öğrencilerin eksik kazanım ve becerilerini tamamladıklarını, öğrencilerle bire bir ilgilenme imkânı bulduklarını, öğrenciler arası seviye farkının azaldığını ifade etmişlerdir. Katılımcılar, IYYEP sürecinin daha etkili ve verimli devam edebilmesi için; öğrenci devamsızlıklarının azaltılması, ders materyallerinin geliştirilmesi, öğretmene ödenen ücretin artırılması, hafta içi program faaliyetlerine öğrencilere yeterince dinlenme imkânı verildikten sonra başlanması, paydaşlara programın içeriği, işleyişi ve önemi hakkında yeterli sayıda ve nitelikli bilgilendirmelerin yapılması önerilerini getirmişlerdir.

Anahtar sözcükler: İlkokullarda Yetiştirme Programı, sınıf öğretmeni, ilkokul.

\begin{abstract}
This research was conducted to examine the problems encountered in the Remedial Program in Primary Schools (RPPS), its contributions to the stakeholders of the program, and the solution suggestions of the participants for the problems experienced during the program. For this purpose phenomenology method was used in research whose study group consisted 50 volunteer teachers was working in primary schools in Dulkadiroğlu and Onikişubat districts of Kahramanmaraş province in the 2018-2019 academic year. The data of the study was collected by using semi-structured interview form. The data were analyzed using content analysis method. In the findings obtained for the problems encountered in the RPPS, participants stated that they face program, legislation, students, guidance, physical infrastructure, and teacher-centered problems. In the findings regarding the contributions of the program to the stakeholders, the teachers stated that they completed the incomplete acquisition and skills of the students by applying RPPS, that they found the opportunity to deal with the students one-on-one, and that the level difference between the students decreased. In order to continue the RPPS process more effectively and efficiently participants suggested that reducing student absenteeism, developing course materials, increasing the fee paid to the teacher, starting the program activities after giving enough rest to the students, providing sufficient and qualified information to the stakeholders about the content, operation and importance of the program.
\end{abstract}

Keywords: Remedial Program in Primary Schools, classroom teacher, primary school.

Bu makaleye atıf vermek için:

Aydın, S. \& Yakar, L. (2020). İlkokullarda yetiştirme programında (IYEP) karşılaşılan sorunlar, paydaşlarına olan katkıları ve Cite this article as: çözüm önerileri. Trakya Eğitim Dergisi, 10(3), 795-814.

Aydın, S. \& Yakar, L. (2020). İlkokullarda yetiştirme programında (IYEP) karşılaşılan sorunlar, paydaşlarına olan katkıları ve çözüm önerileri. Trakya Ĕ̆itim Dergisi, 10(3), 795-814.

\section{EXTENDED ABSTRACT}

\section{Introduction}

Remedial Program in Primary School (RPPS) is a program developed to provide students with individual learning needs in early classes and to support them. The target group of the RPPS is the students who attend the 3rd and 4th grades of primary schools, do not have any special education diagnosis, and do not obtain the gains from the Turkish and mathematics courses within the of

${ }^{1}$ Öğretmen, Milli Eğitim Bakanlığı, Kahramanmaraş/Türkiye, sami.aydin82@ hotmail.com, ORCID: 0000-0003-3491-185X

${ }^{2}$ Dr. Öğr. Üyesi, Kahramanmaraş Sütçü İmam Üni., Eğitim F., Eğitim Bil. Böl. 1_yakar@hotmail.com, ORCID: 0000-0001-78566926 
RPPS. Disadvantaged students, such as foreign students, asylum seekers, refugees, nomadic and seminomadic children, seasonal agricultural workers, are among the target groups of the program. The indirect target group includes classroom teachers, guidance teachers, school administrators and parents.

It is not well known what problems are related to the RPPS, which is very new for Turkey. It is necessary to identify and solve the problems arising from the education of the target student group which is behind their peers in terms of acquisition and skill there fore; there is a need for research on the education of RPPS student group. It is considered by researchers that there is a need for a data set to address the problems that arise in the implementation of the RPPS and these solutions. From this point of view, it is thought that the problems experienced by the teachers in educational activities will be identified and solutions will be provided, the quality of the RPPS trainings will increase and the results obtained will contribute to the literature.

\section{Method}

Phenomenology design, one of the qualitative research methods, was used in the study. In this study, the participants were RPPS teachers or administrators of RPPS schools. Maximum diversity sampling, one of the purposeful sampling methods, was used to identify the participants. Participants consisted of 50 volunteer teachers working in Dulkadiroğlu and Onikişubat districts of Kahramanmaraş province in 20182019 academic year.

In this study, the data was collected via semi-structured interview form which was developed by researchers and which has two parts. The first part of form was consisted of six questions to determine the personal characteristics of the participants, the second part of the form was consisted of three open ended questions which encountered problems of participants related RPPS, contributions to the stakeholders of the program and solution proposals to problems. The opinions of the participants about the program were taken and examined in detail. The data was analyzed using content analysis. Data were read separately by two researchers. Data texts were divided into chunks and codes were generated. Themes were created after common codes were combined and unnecessary codes were removed. Finally, the codes were tabulated and the findings of the research were presented with striking views that could reflect the essence of that theme.

\section{Result and Discussion}

When the problems experienced by the participants during the RPPS process were examined, it was stated that forming groups with a unified classroom approach made it difficult for the students to learn if the students studying in the same course module could not be grouped together. The teachers stated that they found that the additional tuition fee was insufficient and that they should be given the economic and personal rights given to teachers working in the RPPS. In addition, students' absenteeism is another important result found. Students' tiredness in the weekday program planning, classrooms problem, the indifference of the families to the program, inadequate quantity and quality of the course materials are other results.

When the findings related to the contributions of the program to the stakeholders were examined, the teachers stated that they had the opportunity to deal with the students one-on-one during the program process and completed their incomplete acquisition and skills. The participants stated that the students who participated in RPPS have closed the level difference between their peers at the end of the process and they are more active in their formal education courses.

The solutions proposed by the participants for better implementation of the RPPS are in parallel with the problems encountered. One of the most important results of this study is that the stakeholders do not have enough information about the content, operation and importance of the program. Some of the problems stated by the participants such as the indifference of the parents to the program and the absenteeism of the students can be stated that the studies aiming to inform the main reason of the problems are due to the insufficient quantity and quality. In addition to this, the participants also offered solutions for the cooperation of the stakeholders, better planning the implementation steps of the program, easing the paperwork, simplifying the implementation of the measurement tools of the program and breaking the perception of "RPPS student is unsuccessful student". 


\section{GíRiș}

Toplumların en önemli kaynağı insandır. İnsana yapılan yatırım, ülkelerin gelişmesinde öncü bir rol üstlenmektedir. İnsan öğesi, eğitim kurumlarında eğitim süreci ile şekillendirilmektedir. Örgün eğitim ve öğretim faaliyetleriyle bireyler doğrudan, toplum ise dolaylı olarak etkilenmektedir (Nartgün ve Dilekçi, 2016). Ancak bu faaliyetler yapılırken eğitimde planlanan hedefler zaman zaman öğrencilere kazandırılamamakta ve başarısız olunmaktadır (Ünsal ve Korkmaz, 2016). Öğrencilerin düşük performansı; nitelikli insan gücünün yetişememesine, eğitime ayrılan kaynakların boşa harcanmasına, öğrencilerin, öğretmenlerin, velilerin üzülerek motivasyon kaybı yaşamalarına yol açmaktadır (Dam, 2008; Gençoğlu, 2019; Tezcan, 1984). Düşük performans gösteren bireylerin, okula devam etmede motivasyon kayb1 yaşadıkları, okulu tamamen bırakma ihtimallerinin yüksek olduğu bunun da bir ülkenin uzun vadeli ekonomik büyümesini sekteye uğratabilmektedir (OECD, 2016).

Türkiye'de eğitim kalitesinin pek çok OECD ülkesinden düşük olduğu, yüksek ve düşük performanslı öğrenciler arasında akademik açıdan önemli farklar olduğu ifade edilmektedir (Dünya Bankası, 2011; Taş, Arıc1, Ozarkan ve Özgürlük, 2016). Türkiye'de devlet yetkililerinin, düşük performans nedeniyle öğrenciler arası oluşan akademik farkları azaltma kararlılığı 64. Hükümet programında "Öğrenme ve gelişim düzeyi akranlarının gerisinde olan öğrencilerin öğrenmesini desteklemek amacıyla tedbirlerin alınması ve yetiştirme programlarının uygulanması" ifadesiyle belirtilmiştir. Benzer bir şekilde bir diğer üst politika belgesi olan Millî Eğitim Bakanlığı'nın 2015-2019 Stratejik Planı'nda da "Bütün bireylerin bedensel, ruhsal ve zihinsel gelişimlerine yönelik faaliyetlere katılım oranını ve öğrencilerin akademik başarı düzeylerini artırmak" hedefi ortaya konulmuştur. Ülkeler ilkokul eğitimleri sırasında akranlarına göre geride kalmış ve dezavantajlı öğrenciler için erken müdahale programları geliştirip ihtiyaç halinde uygulamaya koymaktadırlar (Gençoğlu, 2019; Toptaş ve Karaca, 2019). Bu bağlamda öğrencilerin temel bilgi ve becerileri kazanarak mezun olmalarını sağlamak amaciyla yetiştirme, destekleme gibi müdahale edici sistemlerin kurulması önerilmektedir (Gür, Çelik, Bozgeyikli ve Yurdakul, 2018).

Millî Eğitim Bakanlığı da okullarda uygulanan program neticesinde belirlenen kazanımları istenilen düzeyde edinemeyen öğrencilere yönelik mevcut programa ek bazı yetiştirici ve destekleyici programlar sunarak eğitimde nitel bir iyileşme sağlayabilmeyi amaçlamaktadır. Bu amaç doğrultusunda Millî Eğitim Bakanlığı, ilkokul 3. ve 4. sınıf öğrencilerinden mevcut programın hedeflerini çeşitli sebeplerle yeterince öğrenemeyen öğrencilere yönelik, bireysel öğrenme ihtiyacının erken sınıflarda ortaya çıkarılarak desteklenmesini hedeflemiş, UNICEF ile işbirliği içerisinde İlkokullarda Yetiştirme Programı (IYEP) geliştirilmiştir (Gençoğlu, 2019).

\section{İlkokullarda Yetiştirme Programı (IYYEP)}

IYYEP, öğrencilerin bireysel öğrenme ihtiyaçlarını erken sınıflarda ortaya çıkararak onların desteklenmesini sağlamak amacıyla geliştirilmiş bir programdır. Program çeşitli bölge ve okul tipinde çalışan öğretmenler, uzun yıllar Milli Eğitim Bakanlığı (MEB) bünyesinde çalışmış akademisyenler ve MEB'in yetkili personellerinin katılımlarıyla yapılan çok sayıda çalıştaylar sonucunda geliştirilmiştir. Bu kapsamda IYEP'in pilotlama çalışmaları, UNICEF ile Millî Eğitim Bakanlığı Temel Eğitim Genel Müdürlügünün iş birliğiyle ilkokulların 3. ve 4. sınıflarında 2017-2018 eğitim ve öğretim yılının ikinci döneminde Ağrı, Ankara (Altındağ, Haymana, Mamak, Sincan ilçeleri), Bingöl, Edirne, Hatay, İstanbul (Bağcilar, Çatalca, Çekmeköy, Esenler, Esenyurt, Kartal, Pendik, Silivri, Sultanbeyli ilçeleri), Konya, Mardin, Ordu, Siirt, Sivas ve Şanlıurfa olmak üzere 12 ilde başlamış olup program daha sonra 2018-2019 eğitim ve öğretim yılında ülke genelinde yaygınlaştırılmıştır (MEB, 2018b).

IYEP' in hedef kitlesinde ilkokulların 3. ve 4. sınıfına devam eden, özel eğitim tanısı olmayan, Türkçe ve matematik derslerinden IYYEP kapsamında belirlenen kazanımları edinemeyen öğrenciler bulunmaktadır. Yabancı uyruklu öğrenciler, sığınmacılar, mülteciler, göçer ve yarı göçer aile çocukları, mevsimlik tarım işçisi çocukları gibi dezavantajlı öğrenciler programın hedef kitlesi içerisinde yer almaktadır. Dolaylı hedef kitlesinde ise sınıf öğretmenleri, rehberlik öğretmenleri, okul yöneticileri ve velilerin olduğu belirtilmiştir (MEB, 2018a).

IYYEP, hâlihazırda uygulanan öğretim programına alternatif bir program değildir. Öğrencilere Türkçe, matematik ve psikososyal destek sunmak amaçlanmıştır. Program Türkçe dersi için okuma, yazma, okuduğunu anlama, matematik dersi için doğal sayılar ve doğal sayılarda dört işlem öğrenme gibi asgari düzeyde öğrencilerin sahip olması gereken kazanımlar belirlenerek hazırlanmıştır. Programın bütün türlerinde yer alan öğrenciler bu süreçte psikososyal açıdan da desteklenmektedir. Psikososyal destek ile program kapsamında hedeflenen kazanımların edinilmesiyle beraber söz konusu becerilerin geliştirilmesi, program süresi boyunca ortaya çıkabilecek devamsızlıkların önüne geçilmesi ve programın içeriği hakkında velilere de rehberlik yapılması hedeflenmektedir (MEB, 2018b; Türk Eğitim Derneği [TEDMEM], 2019). 
Programın ilkeleri şu şekilde ifade edilmiştir (MEB, 2018b):

- IYYEP'e belirlenen kazanım ve becerileri edinemeyen öğrenciler alınır.

- IYEP'e ihtiyaç duyan öğrencilere mevcut okullarında programın uygulanması esastır.

- IYEP'e alınacak öğrenciler için gerekli önleyici tedbirler alınarak onların ayrışma hissine kapılmasına yönelik önlemler alınır.

- IYYP'e alınan öğrencilere programın her aşamasında psikososyal destek sağlanır.

- IYYEP kapsamındaki öğrencilerin programa devamları sağlanır.

- Velilerden, programa devam eden öğrencileri için ücret alınmaz.

\section{IYEP Komisyonları ve Görevleri}

IYYEP'in uygulama adımlarının sağlıklı bir şekilde yürütülmesi için, il ve ilçe milli eğitim müdürlüklerinin yanısıra ilkokullar bünyesinde de IYYEP komisyonları oluşturulmuştur. İYEP Okul Komisyonu, okul müdürü veya müdür yardımcısının başkanlığında en az iki sınıf öğretmeni ve varsa rehberlik öğretmeninden oluşur. IYYEP Okul Komisyonu programa alınacak öğrenci sayılarını ve programda görev alacak öğretmenleri belirlemek, haftalık çalışma çizelgesini hazırlamak, program türü ve modüllerine göre öğrenci gruplarını oluşturmakla sorumludur (MEB, 2018b; TEDMEM, 2019). Programda görev alan sınıf öğretmenlerinin görevleri ise ders vereceği modül ve öğrenci seviyelerine göre plan hazırlayıp uygulamak, öğrencilerin devam durumlarını takip etmek, yaptığ 1 değerlendirme neticesinde öğrencilerin bir üst modüle geçmesine karar vermek, öğrencilere programın her aşamasında psikososyal destek verip, gerektiğinde okul rehber öğretmeninden yardım alarak veli ile sürekli işbirliği yapmaktır.

Bakanlık bu süreçte öğretmenlere destek olmak amacıyla IYYEP sürecinde kullanılmak üzere pek çok doküman (IYYEP Türkçe, matematik öğretmen kılavuz kitapları, IYYEP Türkçe, matematik öğrenci etkinlik kitapları, IYEP Türkçe, matematik öğrenci ek çalışma sayfaları, IYEP psikososyal destek rehberi) hazırlanmıştır (MEB, 2018b). Her bir uygulama adımına yönelik yapılması gereken iş ve işlemler şunlardır:

\section{IYEP'in Uygulama Adımları}

IYEP'in uygulama adımları şu dört basamaktan oluşmaktadır: öğrencilerin tespit edilmesi, eğitimin planlanması ve uygulanması, izleme ve değerlendirme çalışmalarının yapılması ve raporlama (MEB, 2018c).

\section{Öğrencilerin Belirlenmesi}

IYYEP'in ilk uygulama adımı, programa alınacak öğrencilerin tespit edilmesidir. IYYEP'e dahil edilecek öğrenciler Ekim ayının 3. haftasında sınıf öğretmenleri tarafından MEB'in geliştirdiği Öğrenci Belirleme Aracı (ÖBA) uygulanarak belirlenir. ÖBA'nın sorularında Türkçe ve matematik derslerinden açık uçlu ve kısa cevaplı olmak üzere iki tür ölçme tekniği kullanılmaktadır. ÖBA'ya öğrencilerin verdiği cevaplar e-Okul Yönetim Bilgi Sistemi-İYEP İşlemleri modülüne öğrencinin kendi sınıf öğretmeni tarafından işlenir. Herhangi bir sebeple vaktinde ÖBA uygulanmayan öğrenciler için ise program uygulanmaya başlasa dahi ivedi bir şekilde ÖBA uygulanarak gerekiyorsa programa dahil edilmesi sağlanır. Sonuçlar girildikten sonra IYEP okul komisyonu ölçmeden kaynaklanan hatalar nedeniyle ve sınıf öğretmenlerinin başvurusuyla IYYEP öğrenci listesine ekleme ve çıkarma yaparak listenin nihai hale gelmesini sağlar (MEB, 2018a).

\section{Eğitimin Planlanması ve Uygulanması}

Öğrenciler sadece Türkçe, sadece matematik ya da her iki dersten de programa dahil olabilmektedir. IYYP'in hangi tür programına dahil olursa olsun öğrencilere psikososyal destek verilmesi esastır (TEDMEM, 2019). IYYEP'in modüler yapısı içerisinde öğrenciler Türkçe ve matematik deslerinde kademeli olarak üç modülde ilerleyebilmektedir. Modüllerde yer alan kazanımlar ve ders saatleri sayısı Tablo 1'de gösterilmiştir. 
Tablo 1.

Programda yer alan kazanım ve ders saatleri sayısı

\begin{tabular}{lllll}
\hline Alan & $\begin{array}{l}\text { 1. Modül } \\
\text { kazanım sayısı }\end{array}$ & $\begin{array}{l}\text { 2. Modül } \\
\text { kazanım sayısı }\end{array}$ & $\begin{array}{l}\text { 3. Modül } \\
\text { kazanım sayısı }\end{array}$ & $\begin{array}{l}\text { Toplam } \\
\text { kazanım sayısı }\end{array}$ \\
\hline Türkçe & 4 & 8 & 4 & 16 \\
Uygulama süresi & $\mathbf{5}$ & $\mathbf{7 0}$ & $\mathbf{1 5}$ & $\mathbf{9 0}$ \\
\hline Matematik & 10 & 12 & 7 & 29 \\
Uygulama süresi & $\mathbf{2 4}$ & $\mathbf{3 2}$ & $\mathbf{1 4}$ & $\mathbf{7 0}$ \\
\hline Toplam kazanım sayısı & 14 & 20 & 11 & 45 \\
\hline
\end{tabular}

Kaynak: (MEB, 2018b)

IYEP okul komisyonu tarafından öğrencilerin hangi alanda ve hangi modülde eğitim alacağ belirlendikten sonra 1-6 öğrenciyi içeren gruplar oluşturulması esastır. Grup sayısı en fazla 10 öğrenciye kadar çıkabilmektedir. 10 öğrenciden sonra ikinci bir grubun oluşturulması zorunludur (MEB, 2018a). IYEP, hafta içi günde 2 ders saati, hafta sonu ise günde 6 ders saatini, toplamda ise haftada 10 ders saatini geçmeyecek şekilde uygulanır. IYYEP kapsamında görev alan öğretmenlere 10 öğrenciye kadar 160 saati geçmemek kaydıyla yapılacak eğitimler kapsamında ek ders ücreti ödenebilmektedir (MEB, 2018d).

\section{İzleme ve Değerlendirme}

IYYEP sürecinde öğrencilerin değerlendirilmesi üç farklı yaklaşımla yapılmaktadır. İlk değerlendirme yaklaşımı Tanıma ve Yerleştirmeye Yönelik Değerlendirme'dir. Bu aşamada IYYEP kapsamına alınacak öğrenciler ve bunların modül seviyeleri ÖBA ile belirlenmektedir. İkincisi ise İzleme-Biçimlendirmeye Yönelik Değerlendirme'dir. Bu değerlendirme öğretmenlerin öğrencilerin modül içerisindeki kazanımları tamamlama durumlarına göre bir üst modüle geçip geçmeyeceğine karar vermek amacıyla, gözlemlerine dayanarak yaptığı değerlendirmedir. Öğretmenler bu kararı verirken öğrencilerin İYEP öğrenci etkinlik kitapları ve ek çalışma sayfalarına yaptıkları çalışmaları değerlendirerek karar verebilmektedirler. Öğrencilerin modül geçişleri, öğretmenlerin bu kararı verdiği öğrenciler için IYYEP okul komisyonuna görüşlerini ilettikten sonra komisyonun karara bağlamasıyla gerçekleşmektedir. En son modülü tamamlayan öğrenciler için Sonuç Odaklı Değerlendirme yaklaşımı yapılmaktadır. Bu değerlendirmeyle öğrencilerin IYYEP kazanımlarını edinip edinmediğine karar verilir. Bu aşamada Bakanlık tarafından geliştirilen Öğrenci Değerlendirme Aracı (ÖDA) kullanılmaktadır (MEB, 2018b).

\section{Raporlama}

IYYEP modülü e-okul Yönetim Bilgi Sistemi üzerinde yer almaktadır. Okul, ilçe, il raporlarının girilmesi amacıyla geliştirilmiştir. Bu raporlarda; açılan grup sayısı, programa alınan öğrenci sayısı, modül geçişi yapılan öğrenci sayısı, programı bitiren öğrenci sayısı, öğrenci devamsızlıkları, öğretmenlerin görevlendirilmeleri gibi iş ve işlemlere yer verilmektedir (MEB, 2018b).

\section{Araştırmanın Amacı ve Önemi}

IYYEP, Türk eğitim sistemi içerisinde oldukça yeni olan telafi edici bir programdır. İlkokullarda eğitim gören öğrencilerin Türkçe ve matematik derslerinden bireysel öğrenme ihtiyaçlarına erken sınıflarda müdahale etmek amacıyla önemli bir girişim olarak görülmektedir. IYEP yapısı itibariyle temel eğitimde uzun yıllar uygulanabilecek, ilk alınan uygulama çıktıları neticesinde kalıcı etki oluşturabilecek, ulusal bir model olarak tanımlanmıştır (TEDMEM, 2019).

Geniş bir öğrenci grubunu ilgilendiren ve yeni bir uygulama olan IYEP ile ilgili ortaya çıkan sorunlar ve bu sorunlara katılımcıların sunmuş olduğu çözüm önerilerine yönelik yeterince çalışma yapılmış olmaması araştırmanın önemini arttırmaktadır. Alanyazının incelenmesi neticesinde IYYEP konusunda sınırlı sayıda çalışma olduğu görülmüştür. Bunlardan Toptaş ve Karaca (2019) IYYEP kapsamında matematik dersinin değerlendirilmesini amaçlamış, Gürler (2020) ise Fen Bilimleri dersinin IYEP kapsamına dâhil edilip edilmemesine ilişkin öğretmenlerin görüşlerini belirlemeyi amaçlamıştır. Gençoğlu (2019) IYEP için bir derleme çalışması gerçekleştirerek IYEP'in özelliklerini ortaya koymaya çalışmıştır. Avlukyarı (2019) ve Sarıdoğan (2019) ise IYEP'in öğrenci başarısı üzerindeki etkisini belirlemeyi amaçlamışlardır. Bunların yanısıra Dilekçi (2019) ve Kırnık, Susam ve Özbek (2019) çalışmalarında IYYEP 
uygulama sürecinde öğretmenlerin görüşlerine dayalı olarak IYYEP'in artıları ve eksilerini ele almışlardır. Bu çalışmada, öğretmenlerin yaşadıkları sorunlara ilişkin çözüm önerileri, IYYEP'in diğer paydaşlara olan katkılarının detaylıca incelenmesi, farklı okul türlerine ulaşılması ve idarecilerin de görüşlerinin alınması gibi etmenler çalışmayı diğer çalışmalardan ayıran faktörler olarak görülmektedir. $\mathrm{Bu}$ farklılıklar çalışmanın önemini artıran hususlar olarak düşünülmektedir.

Milli Eğitim Bakanlığ IYYEP'in güçlendirilmesi, geliştirilmesi ve başarılı olması için en kritik role sınıf öğretmenlerinin sahip olduğunu değerlendirmektedir (MEB, 2018a). Bu bağlamda IYYEP'te görev alan sınıf öğretmenlerinin program hakkındaki görüşlerinin, eğitim öğretim faaliyetleri içerisinde yaşadıkları sorunlarının tespit edilerek çözüm getirilmesinin IYYEP eğitiminde niteliğin artmasını sağlayan etkenlerden biri olduğu söylenebilir. Öğretmenlerin IYYEP uygulama sürecinde karşılaştıkları sorunlar, IYYEP'in paydaşlarına olan etkileri, IYEP'in daha verimli hale gelmesi için yapılacak düzenlemeler bir veri seti oluşturabilir. $\mathrm{Bu}$ amaç doğrultusunda araştırmanın problem cümlesi "Katılımcıların, İlkokullarda Yetiştirme Programını uygularken karşılaştıkları sorunlar nelerdir ve bu sorunlara hangi çözüm önerilerini getirmektedirler?" şeklinde ifade edilmiştir. Bu genel amaç doğrultusunda aşağıdaki sorulara cevap aranmıştır.

1. Katılımcıların, IYYEP sürecinde karşılaştıkları sorunlar nelerdir?

2. IYEP'in paydaşlarına (öğrenci,öğretmen, veli, okul yöneticileri) katkıları nelerdir?

3. IYEP'in daha etkili ve verimli uygulanabilmesi için katılımcıların önerileri nelerdir?

\section{YÖNTEM}

Bu bölümde araştırmanın modeli, çalışma grubu, verilerin toplanması, analizi, geçerlik ve güvenirlik çalışmaları ile ilgili bilgilere yer verilmiştir.

\section{Araştırmanın Modeli}

Bu çalışmada nitel araştırma yöntemi kullanılmıştır. Nitel araştırma Yıldırım (1999) tarafından tümevarımsal bir süreçte gözlem, görüşme ve doküman analizi gibi yöntemlerle toplanan verilerden hareketle sosyal olguları içinde bulundukları çevreyle araştırmayı ve anlamayı öne çıkaran bir yaklaşım olarak tanımlanmıştır. Araştırmada nitel araştırma yöntemlerinden olgubilim deseni kullanılmıştır. Olgubilim deseninde çevremizde farkında olduğumuz ancak derinlemesine ve ayrıntılı bir bakış açısına sahip olmadığımız olgulara odaklanılmaktadır (Yıldırım ve Şimşek, 2018). Patton (2014) farklı bireylerin düşünceleri ayrıntılı bir şekilde incelenilerek çalışılan olgunun özüne inilebileceğini belirtmiştir. $\mathrm{Bu}$ araştırmada da Kahramanmaraş'ta IYEP'te görev alan katılımcıların programa ilişkin görüşleri alınmış ve detaylı bir şekilde incelenmeye çalışılmıştır.

\section{Araștırma Grubu}

$\mathrm{Bu}$ araştırmada IYEP’te görev alan öğretmenler ya da IYEP okul sorumlusu yöneticilerle çalışılmıştır. Katılımcılar, 2018-2019 eğitim öğretim yılında Kahramanmaraş ili Dulkadiroğlu ve Onikişubat ilçelerinde görev yapan 50 gönüllü öğretmenden oluşmaktadır. Katılımcıların belirlenmesinde amaçlı örnekleme yöntemlerinden, maksimum çeşitlilik örneklemesi kullanılmıştır. Katılımcıların görev yaptığı okulların eğitim şekli tam gün ve ikili eğitimdir. Okul türü olarak da ilçe merkezindeki okullar ile ilçe kırsalında yer alan taşıma merkezli ve birleştirilmiş sınıflı okullar seçilmiştir. Araştırmacılar IYYEP'in uygulandığı tüm okul türlerinden katılımcılarla çalışarak çeşitli okul türleri arasında IYEP'in uygulanmasında ne tür benzerlik ya da farklılıkların olduğunu ortaya koymayı amaçlamışlardır (Yıldırım ve Şimşek, 2018). Araştırmada etik kurallara uygun olarak katılımcıların açık adları yerine onları K1, K2,....K50 şeklinde ifade edecek kodlar verilmiştir. Katılımcıların demografik özellikleri Tablo 2'de verilmiştir.

Tablo 2.

Araştırma grubunun demografik özellikleri

\begin{tabular}{llcc}
\hline Kişisel bilgiler & & $f$ & $\%$ \\
\hline \multirow{2}{*}{ Cinsiyet } & Kadın & 11 & 22 \\
& Erkek & 39 & 78 \\
\hline \multirow{3}{*}{ Mesleki kıdem } & $1-10$ yıl & 10 & 20 \\
& $11-20$ yıl & 23 & 46 \\
& $21-30$ yıl & 14 & 28 \\
& $31-40$ yıl & 3 & 6 \\
\hline
\end{tabular}




\begin{tabular}{llrr}
\hline \multirow{3}{*}{ Yaş } & 21-30 yaş & 7 & 14 \\
& 31-40 yaş & 20 & 40 \\
& $41-50$ yaş & 15 & 30 \\
\multirow{2}{*}{ Görevi } & 51 ve üstü yaş & 8 & 16 \\
& Sinıf öğretmeni & 45 & 90 \\
\multirow{2}{*}{ Okulun eğitim şekli } & Müdür yardımcısı & 3 & 6 \\
& Müdür & 2 & 4 \\
\hline \multirow{2}{*}{ Okulun türü } & İkili eğitim & 22 & 44 \\
& Tam gün eğitim & 28 & 56 \\
\hline \multirow{2}{*}{ Okulun bulunduğu ilçe } & Birleştirilmiş sınıflı ilkokul & 5 & 10 \\
& Taşıma merkezi bünyesindeki ilkokul & 11 & 22 \\
& İlçe merkezindeki ilkokul & 34 & 68 \\
\hline
\end{tabular}

Tablo 2 incelendiğinde araştırma grubundaki kadın katılımcı sayısı on bir (\%22), erkek katılımc1 sayısı otuz dokuzdur (\%78). Katılımcıların yirmi üç tanesi 11-20 yıllık kıdeme (\%46), on dört tanesi 21-30 yıllık kıdeme (\%28), on tanesi 1-10 yıllık kıdeme (\%20), üç tanesi 31-40 yıllık kıdeme (\%6) sahiptir. Araştırma grubundaki katılımcıların yirmi tanesi $31-40$ yaş ( $\% 40)$, on beş tanesi $41-50$ yaş (\%30) yaş, sekiz tanesi 51 ve üstü yaş (\%16), yedi tanesi 21-30 yaş (\%14) aralığında bulunmaktadır. Katılımcıların kırk beş tanesi (\%90) sınıf öğretmeni, beş tanesi (\%10) IYYEP okul sorumlusu yöneticidir. Katılımcıların yirmi sekiz tanesi tam gün (\%56), yirmi iki tanesi ikili eğitim (\%44) yapan kurumlarda çalışmaktadırlar. Katılımcıların otuz dört tanesi ilçe merkezi okul (\%68), on bir tanesi taşıma merkezli okul (\%22), beş tanesi birleştirilmiş sınıflı ilkokullarda (\%10) görev yapmaktadır. Katılımcıların yirmi yedi tanesi Onikişubat ilçesinde (\%54), yirmi üç tanesi Dulkadiroğlu ilçesinde (\%46) görev yapmaktadır.

\section{Verilerin Toplanması}

Nitel araştırmalarda popüler olan veri toplama yöntemlerinden biri de görüşmedir (Creswell, 2017). Balcı'ya (2007) göre kaynak kişilerin ilgi, görüş, tutum ve davranışlarını ortaya çıkarmak amacıyla görüşme yapılabilir. Olgu bilim çalışmalarında yarı yapılandırılmış ya da yapılandırılmamış görüşme formları kullanılır (Aydın, 2015). Bu çalışmada da veriler, araştırmacılar tarafından geliştirilen ve iki bölümden oluşan yarı yapılandırılmış yazılı görüş alma formu kullanılarak toplanmıştır. Görüşme formunun ilk bölümü katılımcıların kişisel özelliklerini belirlemek için dört sorudan, ikinci bölümü ise katılımcıların IYEP ile ilgili karşılaştıkları sorunları ve çözüm önerilerini belirlemek amacıyla üç açık uçlu sorudan oluşmaktadır. Görüșme formu hazırlama aşamasında IYYEP yönergesi incelenmiș, Kahramanmaraș Sütçü İmam Üniversitesi, Sosyal Bilimler Enstitüsü, Eğitim Programları ve Öğretimi Ana Bilim Dalında görev yapan iki öğretim üyesinden uzman görüşü alınmıştır. Aynı zamanda açık uçlu soruların anlaşılması ile ilgili problem olup olmadığını test etmek için programı uygulayan iki öğretmenle pilot uygulama yapılmış, hazırlanan sorular sorularak cevap alınmış, öğretmenlerin görüşlerinden faydalanılarak görüşme formuna son şekli verilmiştir.

Kahramanmaraş İl Milli Eğitim Müdürlüğü’nden araştırma için gerekli izinler alındıktan sonra hazırlanan görüş alma formu, 2018-2019 eğitim öğretim yılı Mayıs ve Haziran aylarında Kahramanmaraş ili Dulkadiroğlu ve Onikişubat ilçelerindeki ilkokullarda görev yapan gönüllü katılımcılara ulaşılarak formu doldurmaları istenmiştir. Katılımcıların görev yaptı̆̆ı okulların \%32'sinin köylerde olması nedeniyle yaşanan ulaşım zorluğu ve katılımcılarla araştırmacıların çalışma saatlerinin uyuşmaması gibi nedenlerle katılımcılarla yüz yüze görüşme yapılamamıştır. Araştırmacılar tespit edilen ilçe merkezindeki okullara gitmiş, okul idarelerine gerekli izinleri göstermiş ve çalışmanın amacı anlatmışlardır. Okul idarelerine görüşme formları bırakılarak yaklaşık bir hafta sonra formlar geri alınmıştır. Köy yerleşim yerinde bulunan okullarında müdür veya müdür yetkili öğretmelerine ulaşılmış, formlar İlçe Milli Eğitim Müdürlüklerinde bulunan haberleşme kutularına bırakılmış yine bu kutulardan formlar geri alınmıştır. Ayrıca bazı köy yerleşim yerindeki okulların idarecilerine formlar e-posta yoluyla gönderilmiş yine aynı şekilde formlara verilen cevaplar e-posta yoluyla alınmıştır. Katılımcılara araştırmanın amacına ulaşması için görüş alma formunun samimi bir şekilde doldurulmaları gerektiği, verdikleri bilgilerin sadece bu bilimsel çalışmada kullanılacağı vurgulanmıştır. Katılımcılardan alınan görüş alma formları dosyalanmıştır.

\section{Verilerin Analizi}

$\mathrm{Bu}$ çalışmadan elde edilen veriler içerik analizi tekniği kullanılarak analiz edilmiştir. İçerik analizinde veriler tanımlanarak, verilerin saklı anlamlarını ortaya çıkarılmaya çalışılır. $\mathrm{Bu}$ analiz 
yönteminde, verilerin birbirine benzeyen bölümleri belirli kavram ve temalarla bir araya getirilip okuyucunun anlayabileceği bir biçimde yorumlanır (Yıldırım ve Şimşek, 2018). Bu araştırmada veriler tümevarımsal bir analize tabi tutularak ortaya çıkan kodlarla kavramsal bir yapı oluşturulmuştur. Veriler iki araştırmacı tarafından ayrı ayrı baştan sona okunmuştur. Veri metinleri parçalara ayrılarak kodlar oluşturulmuştur. Ortak kodlar birleştirilip, gereksiz kodlar çıkarıldıktan sonra temalar oluşturulmuştur. Son olarak kodlar tablolaştırılmış ve kodlarla ilgili o temanın özünü yansıtabilecek çarpıcı görüşlere yer verilerek araştırma bulguları sunulmuştur (Creswell, 2017).

\section{Geçerlik ve Güvenirlik Çalışması}

Lincoln ve Guba (1985) nicel araştırmalardaki "geçerlik" ve "güvenirlik" kavramlarını nitel araştırmalara uygun farklı kavramlarla açıklamaktadırlar. Bu bağlamda iç geçerlilik yerine inandırıcılık, dış geçerlilik yerine aktarabilirlilik; iç güvenlik yerine tutarlılık, dış güvenlik yerine teyit edilebilirlik kavramları kullanılmaktadır (Yıldırım ve Şimşek, 2018).

Araştırmada inandırıcığı sağlamak için araştırma süreci; araştırmanın modeli, çalışma grubunun demografik özellikleri, verilerin toplanması, verilen analizi ayrıntılı bir şekilde anlatılmıştır. Çalışma uzman görüşüne başvurularak düzenlenmiştir. Araştırmacılar toplanan verileri düzenledikten sonra yaptıkları ilk analizin ardından araştırmaya katılan iki katılımcıya sonuçları gösterip değerlendirmelerini isteyerek katılımcı teyidi yapmışlardır. Bu araştırmada aktarabilirliği sağlamak için çalışmanın her aşaması ayrıntılı bir şekilde okuyucuya sunulmuş, okuyucunun anlayabileceği bir dil kullanmaya azami ölçüde özen gösterilmiştir. $\mathrm{Bu}$ amaçla, nitel çalışmalarda geçerlik ve güvenirliği sağlamak için ön plana çıkan yöntemlerden olan katılımcıların görüşlerinden doğrudan alıntılar (Creswell, 2017; Lincoln ve Guba, 1985; Merriam 2018) yapılarak oluşturulan tabloların altında bu görüşlere yer verilmiştir.

Araştırmada katılımcılar amaçlı örneklenme yöntemlerinden maksimum çeşitlilik örneklemesiyle belirlenmiştir. IYYEP'in uygulandığı tüm okul türlerinden katılımcıların görüş bildirmesiyle araştırmanın amacına uygun olarak IYYEP ile ilgili benzer ve farklı düşüncelerin aktarılması sağlanmıştır. Araştırmada tutarlılığı sağlamak adına araştırmacılar birbirinden bağımsız bir şekilde kodlar ve temalar oluşturmuşlardır. Ortak kodlar birleştirilip gereksiz kodlar çıkarıldıktan sonra farklı kodlamanın olduğu yerler incelenmiş, birlikte tartışarak kodun ne olacağına karar verilmiştir. Teyit incelemesinde araştırmacının, tüm veri toplama araçlarını ve elindeki tüm araştırma unsurlarını gerektiğinde ilgililerin incelemesi için saklaması gerekmektedir (Yıldırım ve Şimşek, 2018). Bu çalışmada da veri toplama araçları, yapılan kodlamalar, notlar ve yapılan diğer çalışmalar araştırma adıyla oluşturulan dosyada ve bilgisayar ortamında saklanmıştır.

\section{BULGULAR}

Bu bölümünde araştırmanın alt amaçları doğrultusunda elde edilen bulgular sunulmuştur.

\section{Katılımcıların İYEP Sürecinde Karşılaştıkları Sorunlara İlişkin Görüşleri}

Çalışmanın cevap aradığı birinci soru, IYYEP programında görev alan öğretmenler ve okullardaki IYEP'ten sorumlu yöneticilerin uygulama sürecinde karşıllaştıkları sorunları belirlemektir. Bu amaçla elde edilen bulgular Tablo 3'te verilmiştir.

Tablo 3.

IYEP sürecinde karşılaşılan sorunlar

\begin{tabular}{|c|c|c|c|}
\hline Temalar & Kategoriler & Kodlar & Katılımcılar \\
\hline \multirow{5}{*}{$\begin{array}{l}\text { Program } \\
\text { merkezli sorunlar }\end{array}$} & $\begin{array}{l}\text { Tanılama ve } \\
\text { yerleştirmeye } \\
\text { yönelik problemler }\end{array}$ & $\begin{array}{l}\text { ÖBA'nın yanlış ölçüm } \\
\text { yapması } \\
\text { ÖBA'nın uygulama } \\
\text { sorunu }\end{array}$ & $\mathrm{K} 1, \mathrm{~K} 4, \mathrm{~K} 40$ \\
\hline & \multirow{4}{*}{$\begin{array}{l}\text { Eğitimin } \\
\text { planlanması ve } \\
\text { uygulanmasına } \\
\text { yönelik problemler }\end{array}$} & $\begin{array}{l}\text { Farklı modüldeki } \\
\text { öğrencilerin aynı } \\
\text { sınıfta olması }\end{array}$ & $\begin{array}{l}\text { K5, K19, K22, K25, K26, K27, K32, K41, } \\
\text { K42, K43, K44, K47 }\end{array}$ \\
\hline & & $\begin{array}{l}\text { Program süresinin } \\
\text { yetersizliği }\end{array}$ & K3, K15, K17, K49 \\
\hline & & $\begin{array}{l}\text { Farklı sınıflardan } \\
\text { öğrencilerle ders } \\
\text { yapılması }\end{array}$ & $\mathrm{K} 3, \mathrm{~K} 8, \mathrm{~K} 24, \mathrm{~K} 46$ \\
\hline & & Modül sürelerinin & K6, K7, K34 \\
\hline
\end{tabular}




\begin{tabular}{|c|c|c|c|}
\hline & & $\begin{array}{l}\text { esnek olmaması } \\
\text { Öğrencilerin okuldan } \\
\text { geç saatlerde çımaları }\end{array}$ & K50 \\
\hline & $\begin{array}{l}\text { Sonuç odaklı } \\
\text { değerlendirmeye } \\
\text { yönelik problemler }\end{array}$ & $\begin{array}{l}\text { ÖDA'nın geç } \\
\text { uygulanması } \\
\text { ÖDA'nın uygulama } \\
\text { problemi }\end{array}$ & $\begin{array}{l}\text { K6, K7 } \\
\text { K10, K34 }\end{array}$ \\
\hline & $\begin{array}{l}\text { Hedef kitlesi ile } \\
\text { ilgili problemler }\end{array}$ & $\begin{array}{l}\text { Suriyeli ve Türk } \\
\text { öğrencilerin bir arada } \\
\text { olması }\end{array}$ & K29 \\
\hline \multirow{2}{*}{$\begin{array}{l}\text { Mevzuat/Yönetsel } \\
\text { Merkezli } \\
\text { Sorunlar }\end{array}$} & $\begin{array}{l}\text { Mevzuat ile ilgili } \\
\text { problemler }\end{array}$ & $\begin{array}{l}\text { Ücret yetersizliği } \\
\text { Öğrencilerin taşıma } \\
\text { problemleri }\end{array}$ & $\begin{array}{l}\text { K2, K13, K33, K34, K38, K48, K49 } \\
\text { K18, K44, K46 }\end{array}$ \\
\hline & $\begin{array}{l}\text { Yönetim ile ilgili } \\
\text { sorunlar }\end{array}$ & $\begin{array}{l}\text { Yöneticilerin baskıcı } \\
\text { uygulamaları }\end{array}$ & K36 \\
\hline \multirow{2}{*}{$\begin{array}{l}\text { Öğrenci Merkezli } \\
\text { Sorunlar }\end{array}$} & $\begin{array}{l}\text { Davranış } \\
\text { problemleri }\end{array}$ & Devamsızlık & $\begin{array}{l}\text { K1, K2, K3, K4, K5, K8, K9, K15, K18, } \\
\text { K29, K30, K33, K35, K37, K40, K44, } \\
\text { K45, K46, K47, K48 }\end{array}$ \\
\hline & $\begin{array}{l}\text { Hazır bulunuşluk } \\
\text { problemleri }\end{array}$ & $\begin{array}{l}\text { Öğrencilerin yorgun } \\
\text { olması } \\
\text { Suriye uyruklu } \\
\text { öğrencilerin dil sorunu }\end{array}$ & $\begin{array}{l}\text { K12, K14, K22, K23, K38 } \\
\text { K26 }\end{array}$ \\
\hline \multirow{2}{*}{$\begin{array}{l}\text { Rehberlik } \\
\text { Merkezli } \\
\text { Sorunlar }\end{array}$} & $\begin{array}{l}\text { Bilgi verme } \\
\text { problemleri }\end{array}$ & $\begin{array}{l}\text { Öğretmenlerin } \\
\text { programın işleyişini } \\
\text { yeterince bilmemeleri } \\
\text { Velilerin programın } \\
\text { içeriğini bilmemeleri }\end{array}$ & $\mathrm{K} 20, \mathrm{~K} 21, \mathrm{~K} 45$ \\
\hline & $\begin{array}{l}\text { Psikososyal } \\
\text { problemler }\end{array}$ & $\begin{array}{l}\text { Programdaki } \\
\text { öğrencilerin 'başarısız } \\
\text { öğrencidir' algısı }\end{array}$ & K30, K32, K34 \\
\hline \multirow[t]{2}{*}{$\begin{array}{l}\text { Fiziki Alt Yapı } \\
\text { Merkezli } \\
\text { Sorunlar }\end{array}$} & $\begin{array}{l}\text { Ders materyalleri } \\
\text { ile ilgili problemler }\end{array}$ & $\begin{array}{l}\text { Ders materyallerinin } \\
\text { içeriğinin yetersiz } \\
\text { olması } \\
\text { Ders materyallerinin } \\
\text { geç gelmesi }\end{array}$ & $\begin{array}{l}\text { K17, K18, K23, K29, K30, K31, K32, } \\
\text { K34, K39, K42, K48, K49 } \\
\text { K1, K16, K50 }\end{array}$ \\
\hline & $\begin{array}{l}\text { Fiziki mekân ile } \\
\text { ilgili problemler }\end{array}$ & $\begin{array}{l}\text { Yeterli derslik } \\
\text { olmamas1 }\end{array}$ & K30, K31, K32, K45, K47 \\
\hline $\begin{array}{l}\text { Veli Merkezli } \\
\text { sorunlar }\end{array}$ & $\begin{array}{l}\text { Velinin programa } \\
\text { katılımı ile ilgili } \\
\text { problemler }\end{array}$ & $\begin{array}{l}\text { Velinin ilgisizliği } \\
\text { Velilerin başarılı } \\
\text { öğrencileri programa } \\
\text { dâhil etme isteği }\end{array}$ & $\begin{array}{l}\text { K9, K30, K35, K37, K45, K48 } \\
\text { K9 }\end{array}$ \\
\hline $\begin{array}{l}\text { Öğretmen } \\
\text { Merkezli } \\
\text { Sorunlar }\end{array}$ & Bireysel problemler & $\begin{array}{l}\text { Görev almada } \\
\text { isteksizlik }\end{array}$ & K28 \\
\hline
\end{tabular}

Tablo 3 incelendiğinde IYYEP sürecinde katılımcıların karşılaştıkları sorunlar; program, yönetsel/mevzuat, öğrenci, rehberlik, fiziki alt yapı, veli, öğretmen merkezli temaları altında toplanmıştır. Program merkezli sorunlar; tanılama ve yerleştirme, eğitimin planlanması ve uygulanması, sonuç odaklı değerlendirme ve hedef kitlesi kategorileri altında gruplandırılmıştır. Tanılama ve yerleştirmeye yönelik sorunlarla karşılaşan öğretmenler ÖBA'nın yanlış ölçme yapmasını (K1, K4, K40) ve ÖBA'yı uygulama sürecinde yaşadıklarını (K34) sorun olarak görmektedirler. Örneğin ÖBA'nın yanlış ölçüm yapmasını K4 "IYEP sınavında başarısız ögrrenci sayısının fazla olması, normal zamanlarda yaptığı soruları öğrenciler sınav ortamında yapamamış. Gerçekçi bir ölçme olmamış.” şeklinde ifade etmiştir. ÖBA'yı uygularken yaşanan sorunu K34 "ÖBA'nın uygulanması biraz daha basitleştirilmelidir. Çünkü uygulamada ögretmenin tek tek okuması ve çocuğa yaptırması gereken sorular var. Öğretmenin öğrencileri masasına çağırıp yaptırması zor oluyor." şeklinde vurgulamıştır.

Katılımcıların, IYYEP eğitimlerinin planlanması ve uygulanması ile ilgili yaşadıkları problemler; farklı modüldeki öğrencilerin aynı sınıfta olması (f:12)-(\%24), program süresinin yetersizliği (K3, K15, K49), farklı sinıflardan öğrencilerle ders yapılması (K3, K8, K24, K46), modül sürelerinin esnek olmamas1 
(K6, K7, K34) ve öğrencilerin okuldan geç saatlerde çıkması (K50) şeklindedir. Bu temada katılımcılar en çok farklı modüldeki öğrencilerle birlikte ders yapılmasını sorun olarak ifade etmişlerdir. Konu ile ilgili olarak K19'un görüşü “Birleştirilmiş sinıflı sinıf düzeni öğrenci verimini etkiliyor.” şeklinde iken K47'nin görüşü "Farkl modüldeki ögrencilerle ders yapmak sorun oluyor." şeklindedir. Program süresinin yetersizliğini K3 “Ders süresinin azlı̆̆ önemli, daha fazla ders olabilirdi.” şeklinde açıklamıştır. Modül sürelerinin esnek olmaması konusunda K6 "Modül süreleri esnek olabilirdi. Öğretmen süreyi uzatıp, kısaltma yapabilmeliydi." şeklinde görüşlerini ifade etmiştir. İYEP bitiş saatlerinde öğrencilerin eve dönüşleri ile ilgili yaşadığ1 problemi K50 "Bulunduğum okulun iklim koşulları nedeniyle ögrencilerin gidişlerinde sorunla karşılaş̧ım. ” şeklinde ifade etmiştir.

Katılımcılar, sonuç odaklı değerlendirmeye yönelik olarak ÖDA'nın hem uygulanmasında (K10, K34) hem de uygulama zamanında (K6, K7) sorunlar yaşadıklarını belirtmişlerdir. ÖDA'nın uygulama sürecinde yaşadığ 1 sorunu K10 "ÖDA'nın uygulanmasında sınıflarla modüllerin aynı olduğu kanısıyla uygulamaya gidilmesi büyük sorun oldu." şeklinde ifade ederken, uygulama zamanı konusunda K7'nin görüşü "Okulumuzda IYEP 15 Mart gibi bitmesine rağmen değerlendirme çok geç yapıllyor." şeklindedir. Programın hedef kitlesiyle ilgili K9' un görüşü "Suriyeli ve Türk ögrenciler birlikte eğitim almamal, IYEP sadece Türk ögrencilere verilmelidir." ş̧eklindedir.

Mevzuat/yönetsel merkezli sorunlardan mevzuat kategorisinde yedi katılımcı (\%14) aldıkları ücreti yetersiz bulurken üç katılımcı da (K18, K44, K46) öğrencilerin taşınması konusunda problem yaşadıklarını belirtmişlerdir. Alınan ücretin yetersizliği konusunda K13 görüşünü "Ödenen ücretten dolayı ögrretmen bulmakta zorlandık." şeklinde vurgularken K33'te görüşlerini "Branş ögretmenlerinin Destekleme ve Yetiştirme Kursları (DYK) ile IYEP'in arasındaki ek ders ücreti uçurumu giderilmelidir." şeklindeki cümlesiyle ifade etmiştir. Yaşanan taşıma sorununu K18 "Taşıma ile gelen ögrencilerin IYEP'e ihtiyaçları olduğu halde okula taşıma ile geldikleri için devam edemediler." ş̧eklinde açıklamıştır. Yönetim kategorisinde okul yöneticilerinin baskıcı uygulamalarını K36 "Görev almak istemeyen ögretmene zorla görev verilmesi ve programin gün ve saatleri ile ilgili dayatmalarl, aceleye getirmeleri biz uygulayıclları zorlamıştır.” şeklinde açıklamıştır.

Katılımcılar, öğrenci merkezli sorunlar temasında; öğrenci davranış ve hazır bulunuşluk problemleriyle karşılaştıklarını ifade etmişlerdir. Davranış problemleri kategorisinde öğrencilerin devamsızlık yapması IYEP sürecinde en fazla karşılaş1lan problem olarak belirtilmiştir (f:20)-(\%40). Katılımcılar görüşlerini "devamsızlık, devamın sağlanamaması" gibi kısa kelime ve cümlelerle ifade ederken K46 "Taşıma ile gelip giden ve IYEP'e katılan ögrencilerin devamı konusunda problemler yaşadık." şeklinde ifade etmiştir. Öğrencilerin hazır bulunuşlukları kategorisinde yaşadıkları problemleri kat1lımc1lar; öğrencilerin yorgun olmas1 (K12, K14, K22, K23, K38) ve Suriye uyruklu öğrencilerin dil problemleri (K24, K26) şeklinde belirtmişlerdir. Öğrencilerin yorgunluğunu K14 "Okulda ders bittikten sonra çocuklar IYEP'e alınınca altı saat derse girip çıkmış ve yorulmuşlar. Dikkatlerini toplayamıyorlar. Derse karşı odaklanamıyorlar." şeklinde belirtmiştir. K26 "Suriyeli öğrencilerin dil sorunu” şeklinde görüşünü ifade etmiştir.

Rehberlik merkezli sorunlar bilgi verme ve psikososyal problemler kategorilerinde gruplandırılmıştır. Bilgi verme kategorisinde öğretmenlerin programın işleyişini yeterince bilmemelerini üç katılımc1 (K20, K21, K45), velilerin programın içeriğini bilmemelerini ise iki katılımc1 $(\mathrm{K} 9,21)$ belirtmiştir. K45 konu ile ilgili görüşünü "iYEP modülünü nasıl kullanacağımızı kendimiz deneme yanılma ile ögrendik. En başta verilen seminerlerin içinin boş olmaması, açık, net bilgilendirmeler yapılması gerekir." şeklinde ifade etmiştir. K9 "Ailelerin program hakkında yeterince bilgilendirilmemeleri çocukların hafta sonu gönderilmesi konusunda tereddütlere yol açmıştır." şeklindeki görüşleriyle velilerin program hakkındaki bilgi eksikliğine vurgu yapmıştır. Psikososyal problemler kategorisinde programdaki öğrencilerin "başarısız öğrencidir" algısı ile ilgili olarak üç katılımcı (K30, K32, K34) görüşlerini ifade etmiştir. K30'un konu ile ilgili görüşü "Rehberlik noktasında IYEP'e alınan öğrencilere 'IYEP'li öğrenci başarısız öğrenci' gibi algılar oluştu." ş̧eklindedir.

Fiziki altyap1 merkezli sorunlar, ders materyalleri ve fiziki mekân ile ilgili problemler olarak gruplandırılmıştır. Ders materyallerinin içeriğinin yetersizliği ile ilgili olarak (f:12)-(\%24) katılımcılar görüşlerini belirtmişlerdir. Konu ile ilgili olarak K32'in görüşü "Öğrenci kitaplarının içerikleri yetersiz ve modüllere uygun düzenlenmemiştir.” şeklinde iken K42'nin görüşü “ ...kitapların en basit gruba göre hazırlanması üst seviyedeki ögrencilerin motivasyonunu düşürmektedir. ” şeklindedir. Üç katılımc1 da (K1, $\mathrm{K} 16, \mathrm{~K} 50$ ) ders materyallerinin okullara zamanında gelmediğini belirtmişlerdir.

Katılımcılar, velilerle ilgili yaşadıkları problemleri; velilerin ilgisizliği (f:6)-(\%12) ve velilerin başarılı öğrencileri programa dâhil etme isteği (K9) şeklinde açıklamışlardır. Konu ile ilgili olarak katılımcıların birbirine yakın düşünceleri “Velilerin ilgisiz olması sorunlar oluşturdu.” şeklindedir. K9 
velilerin başarılı öğrencileri programa dâhil etmek istemelerini "Programa başarılı ögrencilerin katılması için velilerin ısrarları ile karşılaşıyoruz." şeklinde ifade etmiştir. Katılımcılardan K28 programda görev alacak öğretmeni bulmakta yaşadığı zorluğu "Öğretmen bulmada sıkıntı yaşanıyor." şeklinde açıklamıştır.

\section{Katılımcıların IYYEP'in Paydaşlarına (Öğretmen, Yönetici, Öğrenci, Veli) Katkılarına İlişkin Görüşleri}

Çalışmanın cevap aradığı ikinci soru, IYYEP'in paydaşları olan öğretmen, yönetici, öğrenci ve veliye olan katkılarını belirlemektir. Bu amaçla elde edilen bulgular Tablo 4 'te verilmiştir.

Tablo 4.

IYEP'in paydaşlarına olan katklları

\begin{tabular}{|c|c|c|c|}
\hline Temalar & Kategoriler & Kodlar & Katılımcılar \\
\hline \multirow{5}{*}{$\begin{array}{l}\text { Öğrenciye } \\
\text { yönelik } \\
\text { katkıları }\end{array}$} & Bilişsel gelişime katkı & $\begin{array}{l}\text { Eksik kazanım ve becerileri } \\
\text { tamamlama }\end{array}$ & $\begin{array}{l}\text { K1, K4, K5, K9, K11, K12, } \\
\text { K14, K15, K19, K21, K22, } \\
\text { K23, K27, K30, K32, K33, } \\
\text { K39, K40, K41, K43, K44, } \\
\text { K48, K49, K50 }\end{array}$ \\
\hline & $\begin{array}{l}\text { Duyuşsal gelişiminine } \\
\text { katk1 }\end{array}$ & $\begin{array}{l}\text { Kendi sınıfindaki derslerde daha aktif } \\
\text { olma } \\
\text { Özgüvenini arttırma } \\
\text { Okula yönelik aidiyet duygusunu } \\
\text { arttırma }\end{array}$ & $\begin{array}{l}\text { K11, K42, K50 } \\
\text { K25, K42 } \\
\text { K31, K32 }\end{array}$ \\
\hline & $\begin{array}{l}\text { Psikomotor gelişimine } \\
\text { katk1 }\end{array}$ & Pratik yapma imkânı bulma & K23, K31 \\
\hline & Dil gelişimine katkı & $\begin{array}{l}\text { Öğretmeniyle daha fazla iletişim } \\
\text { kurma }\end{array}$ & K18 \\
\hline & Sosyal gelişimine katk1 & Okulda daha nitelikli zaman geçirme & K48 \\
\hline \multirow{6}{*}{$\begin{array}{l}\text { Öğretmene } \\
\text { yönelik } \\
\text { katkıları }\end{array}$} & \multirow{2}{*}{$\begin{array}{l}\text { Öğretme öğrenme } \\
\text { sürecine katk1 }\end{array}$} & $\begin{array}{l}\text { Öğrencisiyle bire bir ilgilenme } \\
\text { imkânı bulma }\end{array}$ & $\begin{array}{l}\text { K5, K9, K14, K18, K20, } \\
\text { K21, K23, } \\
\text { K24, K25, K26, K32, K48 }\end{array}$ \\
\hline & & $\begin{array}{l}\text { Öğrenciler arası seviye farkını } \\
\text { kapatma }\end{array}$ & $\begin{array}{l}\text { K9, K13, K19, K23, K31, } \\
\text { K32, K34, K39, K44, K49 }\end{array}$ \\
\hline & Ekonomik katk1 & Maddi katk1 sağlama & $\mathrm{K} 14, \mathrm{~K} 29, \mathrm{~K} 30$ \\
\hline & Öğrenciyi tanımaya katkı & $\begin{array}{l}\text { İYEP öğrenci grubunu yakından } \\
\text { tanıma }\end{array}$ & K10, K50 \\
\hline & Mesleki beceriye katk1 & Derslerde farklı teknikleri kullanma & $\mathrm{K} 40, \mathrm{~K} 46$ \\
\hline & Psikolojik katkı & $\begin{array}{l}\text { Gelişen öğrencisinin durumundan } \\
\text { memnun olma }\end{array}$ & K5, K32 \\
\hline \multirow{2}{*}{$\begin{array}{l}\text { Yöneticilere } \\
\text { yönelik } \\
\text { katkıları }\end{array}$} & $\begin{array}{l}\text { İşbirliği ve iletişime } \\
\text { katk1 }\end{array}$ & Paydaşlarla bir araya gelme & K46 \\
\hline & Psikolojik katkı & $\begin{array}{l}\text { Eğitim öğretim kalitesinin } \\
\text { artmasından memnun olma }\end{array}$ & K5 \\
\hline \multirow{4}{*}{$\begin{array}{l}\text { Veliye } \\
\text { yönelik } \\
\text { katkıları }\end{array}$} & \multirow{2}{*}{ Psikolojik katkı } & $\begin{array}{l}\text { Gelişen öğrencisinin durumundan } \\
\text { memnun olma }\end{array}$ & K5, K49 \\
\hline & & $\begin{array}{l}\text { Öğrencisinin akademik durumunu } \\
\text { kabullenme }\end{array}$ & K19 \\
\hline & Ekonomik katk1 & Ücretsiz takviye fırsatı bulma & K15 \\
\hline & İş yükünü azaltma & $\begin{array}{l}\text { Öğrencisi üzerindeki akademik iş } \\
\text { yükünün azalması }\end{array}$ & K30 \\
\hline
\end{tabular}

Tablo 4 incelendiğinde IYEP'in paydaşları olan öğrenci, öğretmen, yönetici ve velilere birçok alanda katkı sunduğu görülmektedir. Katılımcılar, IYYEP'in öğrencilerin; bilişsel, duyuşsal, psikomotor, dil ve sosyal gelişim alanlarına katkı sağladığını belirtmişlerdir. Katılımcıların (f:24)-(\%48)'i İYEP'in öğrencilerin eksik kazanım ve becerilerini tamamladığını düşünmektedirler. Örneğin K9 konu ile ilgili görüşünü "IYEP ögrencilerin temel becerilerinin gelişmesini sağllyor. Eksiklerini tamamlama firsatı doğuruyor. Merdivenin orta basamaklarındaki kopuk olan ögrrenci yükseklere çıkabilme firsatı buluyor." şeklinde ifade ederken, K41'in görüşü "illkokul 3. ve 4.sınıfa gelen fakat çeşitli nedenlerle okuma-yazma, anlama, doğal sayılarda dört işlem gibi yeterli kazanımlara ulaşamayan ögrenciler için faydalı olmuştur." şeklindedir. 
Katılımcılar, IYEP'in öğrencilerin duyuşsal gelişim alanına yönelik kendi sınıfındaki derslere katılma isteğini (K11, K42, K50), özgüvenlerini (K25, K42) ve okula yönelik aidiyet duygularını arttırdığını (K31, K32) vurgulamışlardır. Öğrencilerin İYEP sonrasında mevcut sınıfındaki derslerde daha aktif olmalarını K11 "IYEP programında iyileştiğini gören ögrrencinin ögrenme isteği, dikkati ve ilgisi artmıştır." şeklinde ifade etmiştir. Öğrencilerin özgüvenlerinin artmasını K25 "Kendilerine özgüvenleri geliyor. Bu onları olumlu etkiliyor. Değerli olduklarını hissediyorlar." şeklinde belirtmiştir. K32 öğrencilerin okula yönelik aidiyet duygusundaki artış1 "Öğrencilerin okulu benimseme, ikinci evi olarak görme ve aidiyet hisleri artmıştır.” şeklinde belirtmiştir.

Katılımcılar, IYYEP sürecinde öğrencilerin, birçok konuda pratik yapma imkânı bulduklarını (K23, K31), öğretmenleriyle daha fazla iletişim kurma imkânı yakaladıklarını (K18), okulda daha nitelikli zaman geçirdiklerini (K48) belirtmişlerdir. K31 "Öğrencilerin okuma, sayılarla uğraşma, materyal ve akıllı tahta kullanma süreleri artmıştır." şeklindeki görüşüyle öğrencilerin psikomotor becerilerinin arttığını ifade ederken, K18 "Öğrenci ögretmeniyle birebir iletişim kurmada daha çok zaman bulduğu için daha rahat bir ortam ve kendisini ifade etmekte ya da anlamadiğ konularda sormakta zorlanmiyor." şeklinde görüşüyle dil gelişimine vurgu yapmış, K48'de "Öğrenciler, arkadaşlarıyla okulda daha iyi zaman geçirmişsir.” şeklindeki görüşüyle programın öğrencilerin sosyal gelişimine olan katkılarını belirtmiştir.

Katılımcılar, IYYEP sürecinin öğretmenlerin; öğrenme öğretme süreçlerine, ekonomilerine, öğrencileri tanımalarına, mesleki becerilerine, psikolojilerine katkı yaptığını belirtmişlerdir. Katılımcılardan on ikisi (\%24) öğretmenlerin öğrencileriyle birebir ilgilenme imkânı bulduklarını belirtirken dokuzu (\%18) öğrenciler arası seviye farkının kapandığını belirtmişlerdir. Öğrencileriyle yakaladığı birebir ilgilenme imkânını K9 "Öğretmenin desteğe ihtiyacı olan ögrencilere derste özel ilgilenme firsatı bulamadı̆̆ için bu uygulama ile bu imkân doğuyor." şeklinde ifade ederken, K20 "Eksiği olan öğrencilerle birebir ilgilenme firsatı buldum." ş̧eklinde ifade etmiştir. IYYEP'in öğrenciler arası seviye farkını kapattığını K44 "Sınıftaki öğrenciler arası seviye farkını büyük ölçüde kapattığı için sınıflarda ders işleme konusunda öğretmenlere büyük faydast olmuştur.” ş̧eklindeki cümlesiyle ifade etmiştir.

Üç katılımc1, IYYEP'in öğretmenlere ekonomik katk1 (K14, K29, K30) sunduğunu, ikişer katılımcı IYYEP öğrenci grubunu yakından tanıma imkânı bulduklarını (K10, K50), derslerde farklı teknikler kullandıklarını (K40, K46) ve gelişen öğrencilerinin durumundan memnun olduklarını (K5, K32) belirtmişlerdir. Katılımcılardan, K30 "Öğretmenlere azda olsa maddi katkı sağlamıştır." şeklindeki cümlesiyle maddi katkıya, K10 "Risk grubu öğrencileri yakından tanıma imkânı buldum." şeklindeki ifadesiyle öğrencileri yakından tanımaya, K46 "IYEP işlenen konuların ögrretmenin zihninde canlı tutulmasını sağlayarak hem kendi sinıfinda hem de IYEP sinıfinda verilecek örneklerin artmasın sağladiğını gözlemledim." şeklindeki açıklamasıyla mesleki beceriye olan katkıya, K32 "Öğretmenler, ögrencilerin başarıları, gelişimleri, uyumları ve gayretleriyle memnuniyet ve mutluluk duymuşlardır." şeklindeki ifadesiyle psikolojik katkıya vurgu yapmışlardır.

Katılımcılar, okul IYYEP sorumlusu yöneticilerin paydaşlarla bir araya gelerek iletişim ve işbirliği içerisinde olduklarını belirtmişlerdir. Konu ile ilgili olarak K46 "IYEP'in öğretmen ve idarecileri ortak bir çabaya yönlendirdiğini gözlemledim." cümlesiyle iletişim ve işbirliğine vurgu yaparken, ayrıca paydaşların aralarında yaptıkları tartışmalar neticesinde IYYEP öğrenci grubundaki öğrencilerin gelişim alanlarındaki ilerlemelerin yöneticileri memnun ettiği ifade edilmiştir. K5 "Okulda eğitim kalitesinin artmasından duyulan huzur ve mutluluk." cümlesiyle yöneticilere olan psikolojik yansımasına vurgu yapmıştır.

IYYEP sürecinin velilere olan katkıları; psikolojik, ekonomik ve akademik iş yükünü azaltma şeklinde kategorilere ayrılmıştır. Katılımcılar, IYEP'in velilere bilgi ve beceri açısından akranlarının gerisinde olan öğrencilerini fark etme ve bu durumu kabullenmelerine olanak sağladığını (K19), uygulanan programla beraber öğrencilerinin tüm gelişim alanlarında göstermiş olduğu ilerlemenin veliyi mutlu ettiğini (K5, K49) belirtmişlerdir. Konu ile ilgili olarak K19 görüşünü "Veli açısından çocuğunun durumunu kabullenmesi daha kolay oluyor." şeklinde ifade ederken K49'da görüşünü "Öğrencide gözlemlenen öğrenme seviyesi artışı veliyi memnun etmiş, ögrenciye olan desteği artmıştır." şeklinde ifade ederek psikolojik katkıya vurgu yapmışlardır.

İYEP sürecinin velilere olan ekonomik yansımasını (K15) "Veliler bu program sayesinde ögrencilerine ücretsiz takviye kursu firsatı bulmuştur." ş̧eklinde ifade ederken, öğrenci üzerindeki akademik yükünün azalmasını (K30) "Veliler açısından ögrencileri ile ögretmenleri daha çok ilgilenmiş velinin yükü biraz hafiflemiştir. ” cümlesiyle ifade etmiştir.

\section{Katılımcıların IYYEP'in Etkili ve Verimli Uygulanabilmesi İçin Önerilerine Yönelik Görüşleri}

Çalışmanın cevap aradığı üçüncü soru IYYEP programının daha etkili ve verimli uygulanabilmesi için katılımcıların önerilerini belirlemektir. Bu amaçla elde edilen bulgular Tablo 5'te verilmiştir. 
Tablo 5.

IYEP'in daha etkili ve verimli uygulanabilmesi için öneriler

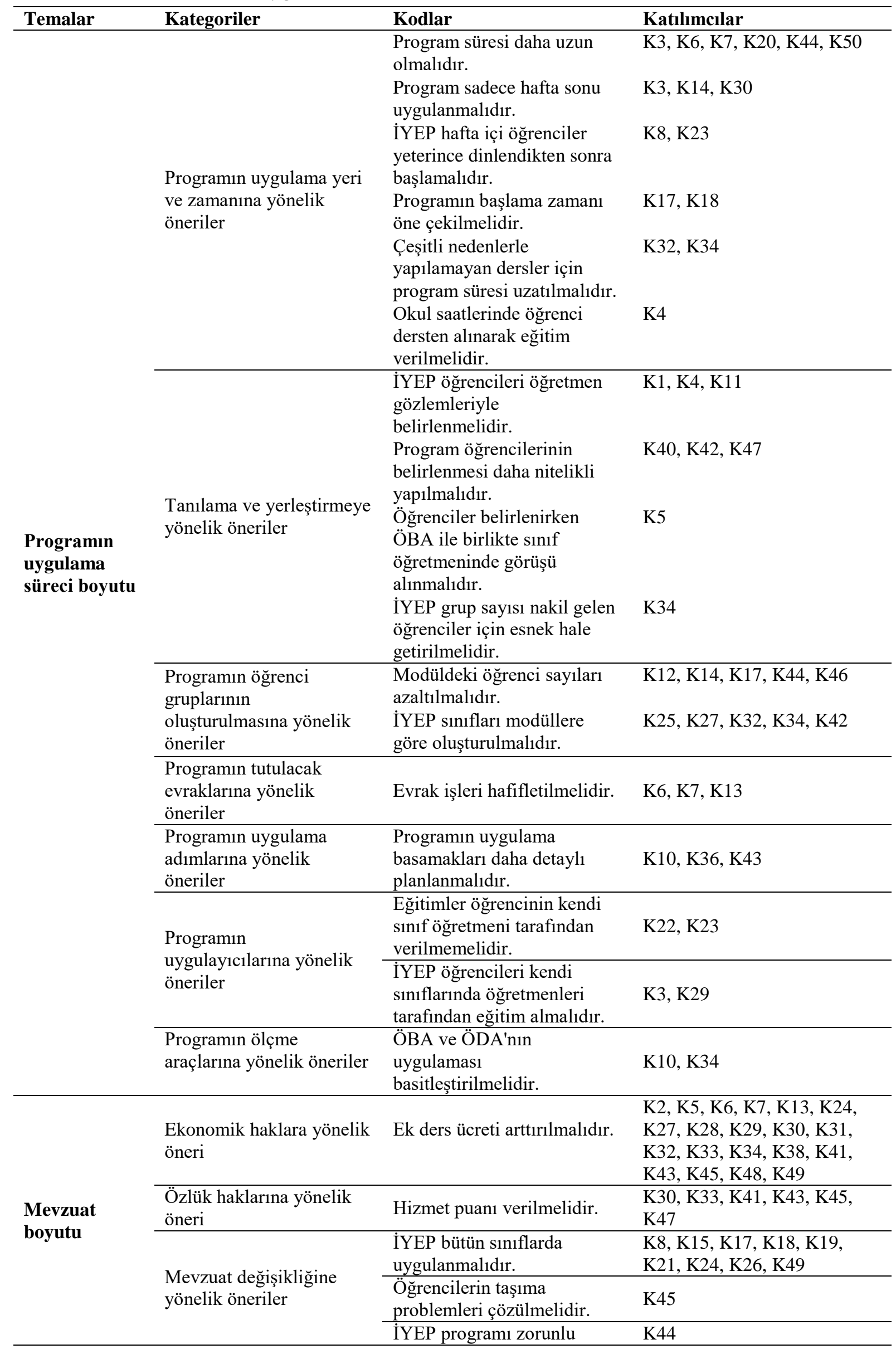


olmalıdır

Örgün eğitimdeki kalite

arttırılarak program

K48

uygulanmamalıdır.

Ders materyallerinin say1s1 $\mathrm{K} 12$, K17, K18, K23, K27,

ve niteliği arttırılmalıdır.

K30, K31, K32, K34, K39,

$\begin{array}{ll}\text { Fiziki alt yapı } & \begin{array}{l}\text { Fiziki alt yapının nitelik } \\ \text { boyutu }\end{array} \\ \text { ve niceliğine yönelik } \\ \text { öneriler }\end{array}$

Okulların derslik sorun

çözülmelidir.

\begin{tabular}{|c|c|c|c|}
\hline $\begin{array}{l}\text { İşbirliği ve } \\
\text { iletişim } \\
\text { boyutu }\end{array}$ & $\begin{array}{l}\text { İşbirliği ve iletişime } \\
\text { yönelik öneriler }\end{array}$ & $\begin{array}{l}\text { Paydaşlar işbirliği içerisinde } \\
\text { olmalıdır. }\end{array}$ & K1, K7, K8, K33, K37 \\
\hline & $\begin{array}{l}\text { Disiplini sağlamaya } \\
\text { yönelik öneriler }\end{array}$ & $\begin{array}{l}\text { Devamsızlıkla ilgili disiplin } \\
\text { sağlanmalıdır. }\end{array}$ & K33, K35, K37, K44 \\
\hline boyutu & $\begin{array}{l}\text { Ödüllendirmeye yönelik } \\
\text { öneriler }\end{array}$ & $\begin{array}{l}\text { Programa katılan } \\
\text { öğretmenler } \\
\text { ödüllendirilmelidir. }\end{array}$ & K31 \\
\hline \multirow{2}{*}{$\begin{array}{l}\text { Rehberlik } \\
\text { boyutu }\end{array}$} & $\begin{array}{l}\text { Bilgilendirmeye yönelik } \\
\text { öneriler }\end{array}$ & $\begin{array}{l}\text { Paydaşlara programın içeriği } \\
\text { ve önemi hakkında } \\
\text { bilgilendirmeler } \\
\text { yapılmalıdır. }\end{array}$ & K5, K9, K13, K16, K35, K45 \\
\hline & $\begin{array}{l}\text { Psikososyal problemlere } \\
\text { yönelik öneriler }\end{array}$ & $\begin{array}{l}\text { İYEP'deki öğrencilerin } \\
\text { 'başarısız öğrencidir' algısı } \\
\text { kırılmalıdır. }\end{array}$ & K30, K34 \\
\hline
\end{tabular}

K42, K45, K47, K48, K49,

K50

K30, K31, K32 kirılmalıdır.

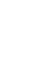

Tablo 5 incelendiğinde katılımcıların IYEP'in daha etkili ve verimli uygulanabilmesi için sundukları öneriler; programın uygulama süreci, mevzuat, fiziki alt yapı, işbirliği ve iletişim, yönetim ve rehberlik temaları altında toplanmıştır. Katılımcılar, bu başlık altında, en fazla programın uygulama süreci ile ilgili öneriler getirmişlerdir. Bu temada, IYYEP programının; uygulama yeri ve zamanı, ögrenciyi tanılaması ve yerleştirmesi, öğrenci gruplarının oluşturulması, uygulayıcıları, türü ve içeriği, tutulacak evrakları, uygulama adımları ve ölçme araçlarına yönelik öneriler gruplandırılmıştır.

Programın uygulama yeri ve zamanıyla ilgili olarak beş katılımc1 (K3, K6, K7, K20, K50) program süresinin daha uzun olmasını, üç katılımcı (K3, K14, K30) programın sadece hafta sonu uygulanmasını, ikişer katılımcı hafta içi öğrenciler yeterince dinlendikten sonra eğitimlerin başlanmasını (K8, K23), programın başlama zamanının öne çekilmesini (K17, K18), çeşitli nedenlerle yapılamayan dersler için program süresinin uzatılmasını (K32, K34), bir katılımcı da öğrencinin okul saatlerinde dersten alınarak eğitim verilmesini (K4) öneri olarak getirmişlerdir. Program süresinin yeterli olmamasını K7 "Okuma yazma bilmeyen bir ögrenci için 160 saat yetersizdir." şeklinde ifade etmiştir. Programın sadece hafta sonu uygulanmasını K3 "Kursların hafta sonu yapılmasının uygun olacağını düşünüyorum." cümlesiyle ifade etmiştir. Hafta içi öğrenciler yeterince dinlendikten sonra program eğitimlerinin başlamasını K23 "Kursa başlamadan önce yeterince ara verip çocukların kafasını boşaltmasına imkân tanınmalıdır." cümlesiyle belirtmiştir. Programın başlama zamanının öne çekilmesini K17 "Okulun başladı̆̆ haftadan itibaren IYEP'li ögrencilerin belirlenip eğitim ögretim yılı içerisinde devam edip uygulanması gerekir." ş̧eklinde ifade etmiştir. Farklı sebeplerle yapılamayan dersler için program süresinin uzatılmasını K34 "Sene içerisinde ögretmenin izinli olması, ögrencilerin devamsızlı yapması gibi mazeretlerden dolayı IYEP bitiş tarihi esnek olmalı, uzatılmalıdır." şeklindeki cümlesiyle belirtmiştir. Öğrencinin örgün eğitim saatleri esnasında sınıfından alınarak program eğitiminin verilmesini K4 "Öğrenci dersten alınarak kurs yapılmalıdır." şeklinde belirtmiştir.

Katılımcıların, tanılama ve yerleştirmeye kategorisindeki önerilerinden dört kod oluşturulmuştur. Bu kodlar; IYEP öğrencileri öğretmen gözlemleriyle belirlenmelidir (K1, K4, K11), öğrencilerin belirlenmesi daha nitelikli yapılmalıdır (K40, K42, K47), ÖBA ile birlikte sınıf öğretmeninde görüşü alınmalıdır (K5) ve İYEP grup sayıs1, nakil gelebilecek öğrenciler için esnek hale getirilmelidir (K34) şeklindedir. K11 "IYEP'e katılacak ögrenciyi ögretmen belirlemelidir. Sinıf ögretmeni öğrencisini daha yakından tanır." şeklindeki ifadesiyle öğretmen gözlemleriyle öğrencilerin belirlenmesine, K42 "Öğrenci gruplarının daha özenli ve homojen gruplara dönüştürülmesi gerekir. Aynı seviyede öğrenciler bir arada bulunmalı. Seçerken daha nitelikli bir sınav uygulanmall" cümlesiyle öğrencilerin belirlenmesinde niteliğin arttırılmasına, K5 "Belirleme aracı ile birlikte öğretmenlerin duygu ve düşüncelerinin alınması gerekir." ifadesiyle öğrenciler belirlenirken sınıf öğretmenlerinin de görüşünün alınmasına, K34 "IYEP dersleri 
başladıktan sonra nakil gelen öğrenciler eğer gruplar onar kişiyi doldurmuşsa yeni grup oluşturulamıyor, mevcut gruplara ekleme yapılamıyor." cümlesiyle grup sayılarının nakil gelen öğrenciler için esnek hale getirilmesine vurgu yapmışlardır.

Katılımcılar, modüldeki öğrenci sayıları azaltılarak (K12, K14, K17, K44, K46) ve IYYEP sınıfları modüllere göre oluşturularak (K25, K27, K32, K34, K42) öğrenci gruplarının belirlenmesine yönelik önerilerini belirtmişlerdir. Konu ile ilgili olarak K46 görüşlerini "IYEP sinıflarının mevcudu daha sınırlı tutulup birebir eğitim imkânı sağlanabilir." ş̧eklinde ifade ederken, K27'de "Her modül tek sinıfta olması gerekir." şeklinde ifade etmiştir.

Katılımcıların, programın evrak işleri (K6, K7, K13) ve uygulama adımlarına yönelik (K10, K36, K43) önerileri gruplandırılmıştır. K13 "Evrak işleri basitleştirilmelidir." şeklindeki görüşüyle program kapsamında tutulacak defter, form vb. evrak yükünün hafifletilmesine vurgu yaparken, K10'da "Uygulama basamakları daha detaylı planlanabilir." şeklindeki görüşüyle uygulama adımlarının daha detaylı planlanması gerektiğine vurgu yapmıştır.

Katılımcılar, İYEP programının uygulayıcılarının belirlenmesiyle ilgili olarak; eğitimler öğrencinin kendi sınıf öğretmeni tarafindan verilmelidir (K3, K29) ve eğitimler öğrencinin kendi sınıf öğretmeni dışındaki başka bir öğretmen tarafından verilmelidir (K22, K23) şeklinde birbirine zıt görüşleri belirtmişlerdir. Konu ile ilgili olarak K29 görüşlerini "Her öğretmen kendi sinıfindaki ögrencilere kurs açması daha doğru olur." ş̧eklinde ifade ederken, K23 “İmkân varsa kursu ögrencilerin sinıf ögretmeni haricindeki bir ögretmen vermeli, bunun öğrencilere ön yargısız ve farklı bir anlatım tarzı sunacağına inanıyorum." şeklinde ifade etmiştir.

Katılımcıların, programın ölçme araçlarıyla ilgili önerileri ÖBA ve ÖDA'nın uygulanması basitleştirilmelidir (K10, K34) şeklindedir.

Katılımcıların mevzuat boyutu ile ilgili önerileri; ekonomik, özlük haklarına yönelik iyileștirmeler ve mevzuatta yapılması istenen değişiklikler kategorilerinde gruplandırılmıştır. Katılımcıların büyük bir kısmının (\%40) görüşü programda ödenen ücretin yetersiz olduğu yönündedir. Konu ile ilgili K2 görüşünü "Ortaokul ve liselerde hafta sonu kurslarında verilen ücretin aynisl IYEP kursu ücreti olarak ödenmesi gerekir." ş̧eklinde ifade ederken K5'de "IYEP'in daha uzun süreli ve ögretmenlerin ayırdiğg zamanın karşılı̆̆ olarak maddi durumunda iyileştirmeler yapılmalıdır." ş̧eklinde ifade etmiştir. Ayrıca K49'da "Ücret ikiye katlanmall, böylece daha çok ögretmenin görev alması sağlanacaktır." şeklinde cümle kurmuştur.

Özlük haklarına yönelik iyileştirmelerle ilgili olarak altı katılımcının (\%12) önerisi programda görev alanlara hizmet puanı verilmesi şeklindedir. K47'in görüşü "Ylllık ek puan verilmeli ki ögretmen hevesle kurs açsın daha çok öğrenci bu imkândan faydalansın.” şeklinde iken K33’ün görüşü “...öğretmene yıpranma payı olarak hizmet puanı verilmeli." şeklindedir.

Katılımcıların mevzuat değişikliğine yönelik önerileri IYEP bütün sınıflarda uygulanmalı (f:9)(\%18), öğrencilerin taşıma problemleri çözülmeli (K45), IYYEP programı zorunlu olmalı (K44), örgün eğitimdeki kalite arttırılarak program uygulanmamalı (K48) şeklindedir. Katılımc1lardan K15 "Program ikinci sınıftan itibaren başlatılırsa öğrencilere katkısı daha fazla olabilir." ve K21 "Bu uygulamaya sadece 3 ve 4. sinıflara dâhil edilmemelidir. Özellikle 1.sınıftan itibaren başlanmalı ki uygulama hedefine ulaşsın." görüşleriyle programın önceki sınıflarda da uygulanması gerektiğini ifade etmişlerdir. Öğrencilerin taşıma problemlerini K45 "Görev yaptlğım okul kırsal bölgede olduğu için çocukların kursa gelip gitmesi büyük sıkıntı. Bölge çok dağııık. MEB'in böyle okullardaki servis problemini çözmesi şart!” şeklinde ifade ederken IYEP' in zorunlu olarak uygulanmasını K44 "IYEP'e kalan ögrencilerin bu programa katılmaları zorunlu olmalı." şeklinde ifade etmiştir. K48 programın uygulanmamasını "Illkokullarda kazanım saylsı azaltılıp Türkçe için okuma, yazma, anlama; matematik için dört işlem hakklyla ögretilirse IYEP kurslarına gerek kalmayacakttr." şeklindeki görüşüyle ifade etmiştir.

Katılımcıların fiziki alt yapının nitelik ve niceliğiyle ilgili olarak önerileri ders materyalleri (f:16)(\%32) ve derslik eksikliği (K30, K31, K32) şeklinde gruplandırılmıştır. Ders materyallerinin sayısı ve içeriğini K23 "Daha nitelikli ve çeşitli kaynak kitaplar tedarik edilmeli." şeklinde ifade ederken K27 görüşünü "Kitaptaki özellikle Türkçe metinlerinin daha kısa ve anlaşıllı olması gerekir." şeklinde ifade etmiştir. Ayrıca K50'de "Gönderilen ders kitapları daha ilgi çekici hale getirilebilir." şeklinde cümle kurmuştur.

Katılımcılar, işbirliği ve iletişim temasında paydaşların işbirliği içerisinde olması (K1, K7, K8, K33, K37) gerektiğini ifade etmişlerdir. K7 “Tüm paydaşlar işbirliği içerisinde olursa istenilen, beklenilen sonuç daha yüksek olacaktır." şeklindeki cümlesiyle işbirliğine vurgu yapmıştır.

Yönetim boyutu temasında yer alan öneriler disiplini sağlamaya ve ödüllendirmeye yönelik olarak gruplandırılmıştır. Katılımcılar, öğrencilerin okula devamının sağlanması (K33, K35, K37, K44) ve 
programda yer alan öğretmenlerin ödüllendirilmesi (K31) yönünde görüşlerini ifade etmişlerdir. Katılımcıların ortak görüşü "Öğrencilerin devamlılı̆̆ săglanmalıdır" şeklindedir. K31'de "Kurslara katılan öğretmenler ödüllendirilmelidir." önerisi ile ödüllendirmeye yönelik görüşlerini ifade etmiştir.

Rehberlik boyutu temasında katılımcılar, bilgilendirme kategorisinde paydaşlara programın içeriği ve önemi hakkında bilgilendirmeler yapılmalı (f:6)-(\%12) önerisini getirirken, psikososyal problemler kategorisinde "IYYEP'li öğrenci başarısız öğrencidir." algısı kırılmalıdır (K30, K34) önerisini getirmişlerdir. Konu ile ilgili olarak K5 görüşünü "Program velilere daha etkili anlatılmall. " şekliyle ifade ederken K9'da "Bu uygulamanın amacı velilere iyi anlatılıp bunun bir firsat olduğu anlatılmalıdır" şekliyle ifade etmiştir. K30 'Rehberlik konusunda biraz daha ciddi çalışarak 'IYEP'li öğrenci başarısız ögrencidir.' algısının yıkılması gerekmektedir.” görüşüyle psikososyal problemlere yönelik önerisini belirtmiştir.

\section{TARTIŞMA, SONUÇ ve ÖNERILER}

Bu çalışmada; İlkokullarda Yetiştirme Programı'nın (IYEP) uygulanmasında ortaya çıkan sorunlar, bu sorunlara getirilen çözüm önerileri ve programın paydaşlarına olan katkıları katılımcıların görüşleri doğrultusunda ortaya konulmak amaçlanmıştır. $\mathrm{Bu}$ amaç doğrultusunda hazırlanan açık uçlu sorularla öğretmen ve idarecilerin görüşleri alınmıştır. Alınan görüşlerin içerik analizleri yapıldıktan sonra bulgular ortaya çıkarılmıştır. Bulgulardan kodlar, kategoriler ve temalar oluşturularak çalışmanın sonuçları ortaya konulmuştur. Bu bölümde ortaya çıkan sonuçlar alanyazında yapılan diğer çalışmalarla karşılaştırılarak yorumlar yapılıp önerilerde bulunulmuştur.

IYYEP sürecinde katılımcıların yaşadığı sorunlar incelendiğinde, gruplarının oluşturulmasında aynı ders modülünde okuyan öğrencilerin bir arada gruplanamaması durumunda birleştirilmiş sınıf yaklaşımı ile gruplar oluşturulmaktadır (MEB, 2018b). Araştırma sonucunda öğretmenler, farklı modüldeki öğrencilerle aynı anda öğretim yapmakta ve öğrencilerin öğrenmesini sağlamakta zorlandıklarını belirtmişlerdir. Kırnık, Susam ve Özbek (2019) yaptıkları çalışmada öğretmenlerin IYYEP'in dersler ve modüllere göre ayrı ayrı uygulanmaması ile ilgili yaşadığı sorunlar araştırmanın sonucuyla benzerlik göstermektedir. Ayrıca Dursun (2006) ve Sağ, Savaş ve Sezer'in (2009) yaptıkları çalışmalarda da bu araştırmanın sonuçlarına benzer şekilde, öğretmenler aynı ders saatinde birden fazla farklı sınıfla eğitim öğretim faaliyetleri içerisinde bulunmanın zorluğunu ifade etmişlerdir.

$\mathrm{Bu}$ araştırmaya göre katılımcılar, IYYEP'te görev alan öğretmenlere ödenen ek ders ücretini yetersiz bulmaktadırlar. Öğretmenler ortaokul ve liselerde Destekleme ve Yetiştirme Kursları (DYK) kapsamında görev alan öğretmenlere ödenen \%100 artırımlı ek ders ücretinin (MEB, 2015) kendilerinede ödenmesini istemektedirler. Ayrıca katılımcı idarecilerde ek ders ücreti düşüklüğü sebebiyle IYYEP'te görev alacak öğretmenleri bulmakta güçlük çektiklerini belirtmişlerdir. $\mathrm{Bu}$ sonuçlar doğrultusunda öğretmenlerin ders dışı yaptıkları program, kurs, etüd gibi faaliyetlerde ödenen yeterli ücretin motivasyonlarını arttırarak görev almalarını teşvik ettiğini, alanyazında yapılan çalışmalarda ortaya koymaktadır (Aküzüm ve Saraçoğlu, 2018; Dilekçi, 2019; Gençoğlu, 2019; Göksu ve Gülcü 2016; Öztürk, 2018; Sarıca, 2019; Ünsal ve Korkmaz, 2016).

Araştırmanın diğer bir sonucu IYEP sürecinde öğrencilerin devamsızlık yapmalarıdır. Katılımcılar tarafından en fazla sorun olarak görülen bu durum (\%40), Sarıdoğan'ın (2019) yaptığı çalışmanın sonuçlarıyla benzerlik göstermektedir. Bu çalışmada da görüş bildiren öğretmenlerin yaklaşı \% $\% 40$ '1 programın uygulanma sürecinde öğrencilerin devamsızlık yapmalarını yaşanan en büyük sorun olarak görmüşlerdir. Alanyazında yapılan çalışmaların sonuçları da bu çalışmayı desteklemektedir (Bozbayındır ve Kara, 2017; Canpolat ve Köçer, 2017; Dilekçi, 2019; Göksu ve Gülcü, 2016; Kırnık, Susam ve Özbek, 2019; Sarıca, 2019; Ünsal ve Korkmaz, 2016; Yirci ve Açıkgöz, 2018). Programa dahil olan öğrencilerin fazlaca devamsızlık yapmasının programdan istenilen çıktıların alınmasına engel olduğu söylenebilir. Ayrıca Altınkurt (2008) çalışmasında özürsüz devamsızlık yapan öğrencilerin akademik başarılarında zıt yönlü bir ilişki olduğunu belirlemiş ve devamsızlığın önüne geçilebilmesi için sebeplerin belirlenmesi gerektiğini ifade etmiştir.

$\mathrm{Bu}$ araştırmada katılımcılar, öğrencilerin yorgun olmalarının hazır bulunuşluk seviyelerini etkilediğini belirtmişlerdir. Özellikle hafta içi örgün eğitim derslerinden sonra yapılan eğitimlerde bu yorgunluğun öğrencilerin ders performanslarını etkilediği ifade edilmiştir (Bozbayındır ve Kara, 2017; Dilekçi, 2019; Ünsal ve Korkmaz, 2016).

$\mathrm{Bu}$ araştırmada, ders materyallerinin nicelik ve nitelik olarak yetersiz olması bulunan diğer bir sonuçtur. Katılımcılar ders materyalleri konusunda, özellikle içeriğinde düzenleme yapılmasını, materyallerin okullara yeterli sayıda ve zamanında gönderilmesini çözüm önerisi olarak sunmuşlardır. Alanyazında yapılan çalışmalarda kurslardaki materyal ve doküman eksikliğiyle ilgili sonuçlar mevcut çalışmanın sonucunu destekler niteliktedir (Bozbayındır ve Kara, 2017; Canpolat, 2017; Canpolat ve 
Köçer, 2017; Dilekçi, 2019; Göksu ve Gülcü, 2016; Kırnık, Susam ve Özbek, 2019; Nartgün ve Dilekçi, 2016; Ünsal ve Korkmaz, 2016; Yirci ve Açıkgöz, 2018).

Programın uygulanmasında derslik sorunuyla karşılaşılmış olması araştırmanın sonuçlarındandır. Ayrıca fiziki mekan ile ilgili yaşanan bu sorunun daha çok ikili eğitim yapılan okullarda görüldüğü söylenebilir. Canpolat ve Köçer (2017) ve Bozbayındır ve Kara (2017) tarafindan yapılan araştırmalarda katılımcılar tarafından kurslarda alt yapı ve fiziki mekan ile ilgili sorunların yaşandığının belirtilmesi bu araştırmanın bulgularılyla benzerlik göstermektedir.

Katılımcıların görüşlerine göre program sürecinde karşılaşılaşılan sorunlardan biri de ailelerin programa yönelik ilgisizliğidir. Canpolat ve Köçer (2017) ve Bozbayındır ve Kara (2017) tarafından yapılan araştırmalarda da katılımcılar kurslara yönelik ailelerin ilgisizliğini belirtmişlerdir. Çelenk (2003) yaptığı araştırmada okul başarıları yüksek olan öğrencilerde ailelerin çocuklarını eğitim açısından destekleyci bir tutum içinde bulundukları sonucuna ulaşmıştır. Bu açıdan bakıldığında ailelerin kazanım olarak akranlarının gerisinde olan öğrencilerine gösterecekleri ilgi çocuklarının programın kazanımlarını elde etmede ve derslere olan motivasyonularını artırmada olumlu etki yapacağı söylenebilir.

Programın paydaşlara katkılarına ilişkin bulgular incelendiğinde öğretmenler, program sürecinde öğrencilerle bire bir ilgilenme imkanı bulduklarını, onların eksik kazanım ve becerilerini tamamladıklarını belirtmişlerdir. Katılımcılar, IYYEP'e dahil olan öğrencilerin süreç sonunda akranlarıyla arasındaki seviye farkını kapattığını, örgün eğitimdeki derslerine de destek olduğunu ifade etmişlerdir. Kaliteli okul öncesi veya okul sonrası eğitim programları akademik eğitimle ilişkilendirildiğinde öğrencinin birçok alanda gelişimine önemli katkılar sunmaktadır (Baker, 2013). 2017-2018 eğitim ve öğretim yılında pilot uygulaması yapılan okullarda IYYEP Öğrenci Değerlendirme Aracı uygulanan öğrencilerin \%87,59'u matematik dersinde, \%79,41'i ise Türkçe dersinde başarı göstermiştir (TEDMEM, 2019). Bu yüksek oranlar programın öğrencilerin akademik eksikliklerini tamamladığını göstermektedir. Öte yandan literatürde yapılan diğer çalışmalarda da kursların öğrencilerin başarılarını arttırdığı, eksik kazanım ve becerileri tamamladığı bulguları mevcut çalışmanın bulgularını desteklemesi açısından önemlidir. $\mathrm{Bu}$ sonuçla beraber okulun genel akademik başarıyı arttırdığı yorumu da yapılabilir (Aküzüm ve Saraçoğlu, 2018; Bozbayındır ve Kara, 2017; Canpolat ve Köçer, 2017; Dilekçi, 2019; Dönmez, Pekcan ve Tekçe, 2016; Göksu ve Gülcü, 2016; Kırnık, Susam ve Özbek, 2019; Nartgün ve Dilekçi, 2016; Sarıca, 2019; Sarıdoğan, 2019; Uğurlu, 2017; Ünsal ve Korkmaz, 2016; Yirci ve Açıkgöz, 2018).

Katılımcılar tarafindan IYEP'in daha iyi uygulanabilmesi için getirilen çözüm önerileri incelendiğinde önerilerin sık karşılaşılan problemlere paralel olduğu görülmektedir. Bu araştırmada, katılımcılar tarafindan ortaya konulan çözüm önerilerinin program sürecinde karşılaşılan en önemli problemler olan; öğrencilerin devamsızlık yapmaları, programa yönelik ders materyallerinin yetersiz oluşu; farklı modüldeki öğrencilerin aynı sınıfta bulunması; ücret yetersizliği, velilerin ilgisizliği, öğrencilerin yorgun olması ve derslik bulmada yaşanan sorunlara yönelik olduğu görülmüştür.

Katılımcıların program merkezli tanılama ve yerleştirmeye yönelik çözüm önerilerinde programın içeriği ve işleyişi hakkında bilgi eksikliklerinin olduğu söylenebilir. IYYEP'e dahil olacak öğrenciler okul komisyonları tarafından işletilmektedir. Öğrenciler merkezden ÖBA ile belirlenmekte ve değerlendirlmektedir. Ölçme hatalarından kaynaklanabilecek hatalı öğrenci yerleştirmelerine karşı komisyon kararıyla IYYEP öğrenci listesine ekleme, çıkarma, öğrencinin modül seviyesinin değiştirilmesi ve modüller arası geçişlerde öğretmenin görüşünü ve takdir hakkını esas alarak işlem yapılabilmektedir (Gençoğlu, 2019; MEB, 2018b).

Katılımcılar, programın uygulama yeri ve zamanına yönelik program süresinin daha uzun olması ve programın başlama zamanının öne çekilmesi çözüm önerilerini getirmişlerdir. Programın doğrudan hedef kitlesi içerisinde yer alan öğrenci gruplarından göçer ve yarı göçer ailelerin çocukları ile mevsimlik tarım işçisi ailelerin çocukları gibi dezavantajlı öğrenciler (MEB, 2018b) Kasım ayı gibi daimi ikamet adreslerine gelmekte Nisan ayı gibi başka yerleşim yerlerine göç etmektedir. Bu durumda programın tüm yıla yayılması ya da başlama zamanının öne çekilmesi gibi çözüm önerilerinin programın doğrudan hedef kitlesindeki bazı öğrenci gruplarına fayda sağlayamayacağı ifade edilebilir. Ayrıca esnek bir yapıda tasarlanan program, yaşanan aksaklıklar nedeniyle hafta içi ya da hafta sonu uygulanmasına IYYEP okul komisyonu karar verebilmektedir (MEB, 2018b).

Katılımcılar, farklı modülde ve dersteki öğrencilerle birleştirilmiş sınıf yaklaşımı ile yapılan eğitimin kendilerine yarattığı soruna, IYYEP sınıflarının modül bazlı bir modelle oluşturulması çözüm önerisini getirmişlerdir. Ayrıca zaten akranlarının gerisinde olan bu öğrencilerle bire bir ilgilenmek için modüldeki öğrenci sayılarının azaltılması gerektiğini de ifade etmişlerdir.

Katılımcılar, programda görev almak isteyen öğretmenlerin motivasyonlarının artması ve görev almada daha istekli olmaları için DYK kurslarında görev alan öğretmenlere verilen ekonomik hak ve özlük 
haklarının kendilerine de verilmesi gerektiğini belirtmişlerdir. Bozbayındır ve Kara (2017) yaptıkları çalışmada DYK kurslarında yapılan ek ders ücreti artırımı ve hizmet puanı verilmesi (MEB, 2015) düzenlemesinden sonra öğretmenler açısından kursların cazip hale gelerek motivasyonlarını arttırdığı sonucu mevcut çalışmadaki katılımcıların beklentilerini doğrular niteliktedir. Kırnık, Susam ve Özbek (2019) yaptıkları araştırmada “IYEP’te görev alan sınıf öğretmenlerine ödenen ücretin az olması” bulgusu çalışmanın sonucunu desteklemektedir. Ayrıca alanyazında yapılan diğer çalışmalarda araştırmanın bu sonucuyla benzerlik göstermektedir (Aküzüm ve Saraçoğlu, 2018; Dilekçi, 2019; Gençoğlu, 2019; Göksu ve Gülcü, 2016; Öztürk, 2018; Sarıca, 2019; Sarıdoğan, 2019; Ünsal ve Korkmaz, 2016).

Katılımcılar, programın ilkokul kademesinde bütün sınıf seviyelerinde uygulanmasını önermektedirler. Program asgari düzeyde kazanımları edinemeyen öğrencilere yöneliktir (MEB, 2018a). Dolayısıyla birinci ve ikinci sınıfta Türkçe ve matematik derslerinde temel kazanım ve becerilerde eksikliği olan öğrencilerde, sınıf öğretmenlerinin ufak bir gayreti ile bu eksikliklerin giderilebileceği yorumu yapılabileceğinden program sadece 3.sınıf öğrencilerine uygulanmaktadır (MEB, 2018c). 2017-2018 eğitim öğretim yılında IYYEP Öğrenci Değerlendirme Arac1 uygulanan öğrencilerin \%12,41'i matematik dersinde, \%20,59'u ise Türkçe dersinde IYYEP kapsamıda başarı sağlayamaması (TEDMEM, 2019) 20182019 eğitim öğretim yılında 3. ve 4. sınıflara uygulanan programın 2019-2020 eğitim öğretim yılından itibaren sadece 3. sınıflara uygulanması bir engel olarak görülebilir. Başarı sağlayamayan bu kapsamdaki öğrenciler 4.sınıfta bu kazanımları telafi etme imkanından mahrum kalacaklardır. Dolayısıyla programın 3. ve 4.sınıflarda uygulanması daha gerçekçi görülmektedir.

$\mathrm{Bu}$ çalışmanın en önemli sonuçlarından biri de paydaşların programın içeriği, işleyişi ve önemi hakkında yeterli bilgiye sahip olmamalarıdır. Katılımcıların belirttiği sorunların bir kısmı, velilerin programa olan ilgisizliği, öğrencilerin devamsızlığg gibi problemlerin temel nedeni bilgilendirmeye yönelik çalışmaların nicelik ve nitelik olarak yetersiz oluşandan kaynaklanmakta olduğu ifade edilebilir. Kırnık, Susam ve Özbek (2019) yaptıkları araştırmada “iYEP'e yönelik öğretmen eğitimlerinin olmaması" bulgusu çalışmanın sonucunu desteklemektedir. Alanyazında yapılan çalışmalar incelendiğinde de yapılan toplantı, hizmetiçi faaliyetler ve kursların bu gibi bilgi eksikliklerini gidererek katılımcıları yenilediği sonucu mevcut çalışmayı desteklemektedir (Aydın, 2008; Dilekçi, 2019; Doğan, 2009; Güney, 2018; Kulaz, 2013; Urlunç, 2017).

Katılımcılar, bunların dışında program sürecinin daha etkili verimli olabilmesi için; paydaşların işbirliği içerisinde olması, programın uygulama basamaklarının daha iyi planlanması, evrak işlerinin hafifletilmesi, programın ölçme araçlarının uygulanmasının basitleştirilmesi ve IYYEP'li öğrenci 'başarısız öğrencidir' algısının kırılması çözüm önerilerini de sunmuşlardır.

\section{IYEP'in daha iyi uygulanabilmesi için araştırmacılar tarafından aşağıdaki öneriler sunulmuştur:}

1- Katılımcılardan elde edilen verilerde IYEP'in sürekli olarak kurs olarak ifade edildiği görülmüştür. İYEP'in mevcut programa alternatif bir program olmadığı yapılacak hizmet içi faaliyetleriyle yönetici ve öğretmenlere, toplantılarla da velilere aktarılarak programın felsefesine yönelik algıların yönlendirilmesi sağlanmalıdır.

2- Öğrencilerin devamsızlık problemiyle ilgili olarak program zorunlu hale getirilebilir.

3- Ders mateyallerinin içeriği daha ilgi çekici ve modüler bazda hazırlanabilir. Eğitim ve Biliş̧im Ağı (EBA) üzerinden de ulaşılabilecek dijital içerikler geliştirilebilir.

4- İYEP tüm ilkokullarda uygulandığ i için okullara fiziki alt yapı, öğretmen, öğrencilerin taşınması, yemek desteği gibi ihtiyaçlar konusunda destek olunmalıdır.

5- Öğretmenlerin ve yöneticilerin ekonomik ve özlük hakları DYK kurslarında görev yapan öğretmenlerle denk hale getirilmelidir.

6- Araştırmada sadece öğretmen ve yöneticilerin görüşleri alınmıştır. Yapılacak farklı çalışmalarda öğrenci ve velilerinde görüşleri alınabilir.

\section{KAYNAKLAR}

Aküzüm, C. ve Saraçoğlu, M. (2018). Ortaokul öğretmenlerinin destekleme ve yetiştirme kurslarına yönelik tutumlarının incelenmesi. Turkish Journal of Educational Studies, 5(2), 97-121.

Altınkurt, Y. (2008). Öğrenci devamsızlıklarının nedenleri ve devamsızlığın akademik başarıya olan etkisi. Dumlupinar Universitesi Sosyal Bilimler Dergisi, 20, 129-142.

Avlukyarı, N. T. (2019). Ilkokullarda Yetiştirme Programı (IYEP)'in ögretmen ve yöneticiler tarafindan değerlendirilmesi (Mersin ili Tarsus ilçesi örneği). Yayımlanmamış yüksek lisans tezi. Sakarya Üniversitesi, Eğitim Bilimleri Enstitüsü, Sakarya. 
Aydın, D. (2008). Öğretmenlerin, yöneticiler tarafindan hizmetiçi ĕgitim programları desteklenmesi sonucunda kazandıkları bilgi ve becerileri eğitime yansıtma düzeylerinin incelenmesi. Yayımlanmamış yüksek lisans tezi. Yeditepe Üniversitesi, Sosyal Bilimler Enstitüsü, İstanbul.

Aydın, S. (2015). Olgu bilim araştırmaları. M. Metin (Ed.), Bilimsel araştırma yöntemleri. Ankara: Pegem Akademi.

Baker, E. (2013). The importance of afterschool programs in education reform worldwide: Making it essential in America. Expanding minds and opportunities: Leveraging the power of afterschool and summer learning for student success. Washington, DC: Collaborate Communications Group.

Balcı, A. (2007). Sosyal bilimlerde araştırma yöntem, teknik ve ilkeler. Ankara: Pegem A Yayıncılık.

Bozbayındır, F. ve Kara, M. (2017). Destekleme ve yetiştirme kurslarında (DYK) karşılaşılan sorunlar ve öğretmenler görüşleri temelinde çözüm önerileri. Sakarya University Journal of Education, 7(2), 324-349.

Canpolat, U. (2017). Destekleme ve yetiştirme kursları bağlamında sosyal bilgiler ögretmenleri, kurs merkezi yöneticileri ve ögrenci görüşleri (Eskişehir ili örneği). Yayımlanmamış yüksek lisans tezi. Ondokuz Mayıs Üniversitesi, Eğitim Bilimleri Enstitüsü, Samsun.

Canpolat, U. ve Köçer, M. (2017). Destekleme ve yetişirme kurslarının TEOG bağlamında sosyal bilgiler öğretmenlerinin görüşlerine dayalı olarak incelenmesi. Anadolu Journal of Educational Sciences International, $7(1), 123-154$.

Creswell, J. W. (2017). Eğitim araştırmaları: Nicel ve nitel arştırmanın planlanması, yürütülmesi ve değerlendirilmesi. (Çev. Ed. H. Ekşi) İstanbul: Edam Yayınları.

Çelenk, S. (2003). Okul başarısının ön koşulu: Okul aile dayanışması. İlköğretim Online Dergisi, 2(2), 28-34.

Dam, H. (2008). Öğrencinin okul başarısında aile faktörü. Hitit Üniversitesi İlahiyat Fakültesi Dergisi, 7(14), 75-99.

Dilekçi, Ü. (2019). İlkokullarda yetiştirme programına (IYEP) ilişkin öğretmen görüşleri. Milli Eğitim Dergisi, 48(1Özel Say1), 433-454.

Doğan, O. (2009). Hizmetiçi eğitime katılımın ĕgitim öğretim sürecine etkisi ile ilgili yönetici ve öğretmen görüşleri. Yayımlanmamış yüksek lisans tezi. Maltepe Üniversitesi, Sosyal Bilimler Enstitüsü, İstanbul.

Dönmez, İ., Pekcan, N. ve Tekçe, M. (2016). Destekleme ve yetiştirme kurslarının yönetici, öğretmen ve öğrenci görüşlerine göre değerlendirilmesi. 25. Ulusal Ĕgitim Bilimleri Kongresi (s. 168-169). Antalya: İstanbul Kültür Üniversitesi, 21-24 Nisan 2016.

Dursun, F. (2006). Birleştirilmiş sınıflarda eğitim sorunları ve çözüm önerileri. Sosyal Bilimler Araştırmalar Dergisi 2, 33-57.

Dünya Bankası. (2011). Türkiye'de temel eğitimde kalite ve eşitliğin sağlanması: Zorluklar ve seçenekler. Dünya Bankası, İnsani Kalkınma Departmanı, Avrupa ve Orta Asya Bölgesi.

Gençoğlu, C. (2019). Milli bir destekleme ve yetiştirme sistemi modeli: İlkokullarda yetiştirme programı (IYEP). Millli Ĕ̌itim Dergisi, 48(1-Özel Say1), 853-881.

Göksu, İ. ve Gülcü, A. (2016). Ortaokul ve liselerde uygulanan destekleme kurslarıyla ilgili öğretmen görüşleri. Bayburt Eğitim Fakültesi Dergisi, 11(1), 153-171.

Güney, B. (2018). Sınıf öğretmenlerinin hizmetiçi eğitim programlarına iliş̧kin görüşleri. Yayımlanmamış yüksek lisans tezi. İnönü Üniversitesi, Eğitim Bilimleri Enstitüsü, Malatya.

Gür, B. S., Çelik, Z., Bozgeyikli, H. ve Yurdakul, S. (2018). Eğitime bakış 2018: İzleme ve değerlendirme raporu. Ankara: Eğitim-Bir-Sen Stratejik Araştırmalar Merkezi.

Gürler, S. A. (2020). Fen bilimleri dersinin İlkokullarda Yetiştirme Programına (İYEP) dahil edilmesine ilişkin öğretmen görüşleri. Yüzüncü Yll Üniversitesi Eğitim Fakültesi Dergisi, 17(1), 266-294.

Kırnık, D., Susam, E. ve Özbek, R. (2019). IYYEP (İlkokullarda Yetiştirme Programı) uygulamalarına ilişkin sınıf öğretmenlerinin görüşleri. Milli Eğitim Dergisi, 48(1-Özel sayı), 387-415.

Kulaz, E. (2013). Illkokul öğretmenlerinin kendilerine yönelik hizmetiçi eğitim uygulamalarının koşulları ve verimliliği hakkındaki görüşleri. Yayımlanmamış yüksek lisans tezi. Yeditepe Üniversitesi, Sosyal Bilimler Enstitüsü, İstanbul.

Lincoln, Y. S. \& Guba, E. G. (1985). Naturalıstıc Inquıry. California: Sage Publications.

MEB. (2018a). 30 soruda ilkokullarda yetiştirme programı (IYEP). Ankara: Miili Ĕ̆itim Bakanlı̆̆ı Temel Eğitim Genel Müdürlüğü.

MEB. (2015). Bazı kanun ve kanun hükmünde kararnmalerde değişklik yapılması hakkında kanun. Resmi Gazete: http://www.resmigazete.gov.tr/eskiler/2015/04/20150415-1.htm (Erişim tarihi: 17/08/2019).

MEB. (2018b). Illkokullarda yetiştirme programı (IYYEP) uygulama kılavuzu. Ankara: Temel Eğitim Genel Müdürlüğü.

MEB. (2018c). Illkokullarda yetiştirme programı sunumu. Ankara: Temel Eğitim Genel Müdürlüğü.

Merriam, S. B. (2018). Nitel araştırma: desen ve uygulama için bir rehber (3.bas.). (Çev. S. Turan) Ankara: Nobel Akademik Yayıncılık.

MEB. (2018d). Yönetici ve Öğretmenlerin Ders ve Ek Ders Saatlerine İlişkin Kararda Değişlik Yapılmasına Dair Karar. Resmi Gazete. http://www.resmigazete.gov.tr/eskiler/2018/08/20180831-5.pdf (Erişim tarihi: 01/09/2019).

Nartgün, Ş. S. ve Dilekçi, Ü. (2016). Eğitimi destekleme ve yetiştirme kurslarına ilişkin öğrenci ve öğretmen görüşleri. Kuram ve Uygulamada Ĕ̌itim Yönetimi, 22(4), 537-564.

OECD. (2016). Low-performing students: Why they fall behind and how to help them succeed. Paris: OECD Publishing. 
Öztürk, O. (2018). Destekleme ve yetiştirme kurslarında görev alan öğretmenler ile görev almayan öğretmenlerin mesleki doyum düzeyleri. Yüksek lisans tezi. Çanakkale Onsekiz Mart Üniversitesi, Eğitim Bilimleri Anabilim Dalı, Eğitim Yönetimi ve Denetimi Bilim Dalı, Çanakkale.

Patton, M. Q. (2014). Nitel Araştırma ve Değerlendirme Yöntemleri. (Çev. Ed. M. Bütün ve S.B. Demir) (1.b.). Ankara: Pegem Akademi Yayıncilık.

Sağ, R., Savaş, B. ve Sezer, R. (2009). Burdur'daki birleştirilmiş sınıf öğretmenlerinin özellikleri, sorunları ve ihtiyaçları. Ín̈nü Üniversitesi Eğitim Fakültesi Dergisi, 10(1), 37-56.

Sarıca, R. (2019). Destekleme ve yetiştirme kurslarına (DYK) yönelik öğretmen görüşleri. Milli Ĕ̆itim Dergisi, 48 (221), 91-122.

Sarıdoğan, E. (2019). Illkokullarda yetiştirme programının 3 .ve 4. sınıf öğrencilerinin başarılarına etkisi. Yayımlanmamış yüksek lisans tezi. Adnan Menderes Üniversitesi, Sosyal Bilimler Enstitüsü, Aydın.

Taş, U. E., Arıcı, Ö., Ozarkan, H. B. ve Özgürlük, B. (2016). PISA 2015 ulusal raporu. Ankara: Milli Eğitim Bakanlığı, Ölçme Değerlendirme ve Sınav Hizmetleri Genel Müdürlüğü.

TEDMEM. (2019). 2018 eğitimi değrlendirme raporu (TEDMEM Değerlendirme Dizisi 5). Ankara: Türk Eğitim Derneği.

Tezcan, M. (1984). Okulda başarısızlık ve önlenmesi. Ankara Üniversitesi Eğitim Bilimleri Fakültesi Dergisi, 17(1), 385-388.

Toptaş, V. ve Karaca, E. T. (2019). İlkokullarda yetiştirme programı (IYYEP) kapsamındaki matematik derslerini yürüten sınıf öğretmenlerinin görüşlerinin incelenmesi. Milli Eğitim Dergisi, 48(1-Özel say1), 413-431.

Uğurlu, F. (2017). Destekleme ve yetiştirme kurslarında görevli öğretmenlerin kurslara yönelik öz algl düzeylerinin incelenmesi (Ordu ili örneği). Yayınlanmamış yüksek lisans tezi. Amasya Üniversitesi, Sosyal Bilimler Enstitüsü, Amasya.

Urlunç, O. (2017). Okul yöneticilerinin hizmetiçi ĕ̌itim programlarına ilişkin görüşleri. Yayımlanmamış yüksek lisans tezi. Kafkas Üniversitesi, Sosyal Bilimler Enstitüsü, Kars.

Ünsal, S. ve Korkmaz, F. (2016). Destekleme ve yetiştirme kurslarının işlevlerine ilişkin öğretmen görüşlerinin incelenmesi. KSÜ Sosyal Bilimler Dergisi, 13(2), 87-118.

Yıldırım, A. (1999). Nitel araştırma yöntemlerinin temel özellikleri ve eğitim araştırmalarındaki yeri ve önemi. Ĕ̌gitim ve Bilim, 23(112), 7-17.

Yıldırım, A. ve Şimşek, H. (2018). Sosyal bilimlerde nitel araştırma yöntemleri (11. b.). Ankara: Seçkin Yayıncılık.

Yirci, R. ve Açıkgöz, R. M. (2018). Destekleme ve Yetiştirme kurslarına yönelik yönetici öğretmen ve öğrenci görüşlerinin incelenmesi. 5.Uluslararası eğitim bilimleri sempozyumu tam metin kitabı (s. 169-204). Elazığ: Asos Yayınları. 